\title{
Variation in the diet and breeding biology of the Common Barn-owl (Tyto alba) in a demographic cycle of Common Vole (Microtus arvalis) between two outbreaks ${ }^{\times}$
}

\author{
Adrienn Horváth ${ }^{1}$, László BANK ${ }^{2}$ \& Győző F. Horváth ${ }^{1 *}$
}

${ }^{\times}$Presented at $2^{\text {nd }}$ Hungarian Owl Research Conference held in Pécs on $11^{\text {th }}$ September 2020.

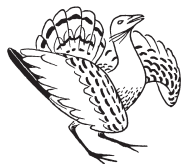

Received: November 05, 2020 - Revised: November 22, 2020 - Accepted: November 23, 2020

Horváth, A., Bank, L. \& Horváth, Gy. F. 2020. Variation in the diet and breeding biology of the Common Barn-owl (Tyto alba) in a demographic cycle of Common Vole (Microtus arvalis) between two outbreaks - Ornis Hungarica 28(2): 37-65. DOI: 10.2478/orhu-2020-0016

\begin{abstract}
In the present study, we analysed the variation of breeding parameters and the diet composition of the Common Barn-owl (Tyto alba) in three different demographic phases of the Common Vole (Microtus arvalis) in a complete population cycle between two outbreaks. The study was conducted in the south-eastern part of the Transdanubian region in South Hungary. For the analysis, we used data of 81 randomly selected first clutches from 2015 to 2019, a time period which represented a full demographic cycle of the Common Vole after the 2014 outbreak with an exceptionally high peak. We tested the impact of prey abundance and diversity of diet composition as continuous predictors as well as the demographic phase of Common Vole and the mesoregion as categorical explanatory variables on the measured reproductive outputs as response variables using Generalized Linear Models (GLM). Considering the breeding parameters, the number of fledglings, and fledging and reproductive success were significantly higher in the increase phase than during the vole crash phase. Based on GLM models, our results demonstrated that the clutch size of the Common Barn-owl is determined ultimately by the availability and consumption rate of the Common Vole as main prey, while other small mammal prey categories did not affect the clutch size. These results support the finding that the clutch size of vole-eating raptors and owls, which begin breeding periods in early spring predicts the vole abundance in this early spring period. Considering the other investigated small mammal prey groups, the alternative prey role was confirmed only in case of the Murid rodent prey categories (Apodemus spp., Muridae).
\end{abstract}

Keywords: reproductive output, food consumption, alternative prey, outbreak

Összefoglalás Jelen tanulmányban a gyöngybagoly (Tyto alba) szaporodásbiológiai paramétereinek és táplálékösszetételének változását vizsgáltuk a mezei pocok (Microtus arvalis) egy teljes populációciklusában elkülönülö három demográfiai fázis során. A vizsgálat Dél-Magyarországon, a Dunántúl dél-keleti részén, Baranya megyében valósult meg. Az elemzéshez a 2015-2019 közötti időszakból 81 rétegzett random mintavétellel kiválasztott első költés adatait használtuk fel, amely reprezentálta a mezei pocok 2014-ben jellemző kiugró gradációja utáni teljes demográfiai ciklust. Általánosított lineáris modellek (GLM) alkalmazásával teszteltük a zsákmány abundancia, a táplálék-összetétel diverzitása, mint folytonos prediktorok, valamint a mezei pocok demográfiai fázisai és a mezorégiók, mint kategoriális magyarázó változók szaporodási kimenetekre gyakorolt hatását. A kirepült fiókák száma, valamint a kirepülési és szaporodási siker szignifikánsan magasabb volt a mezei pocok növekvő fázisában, mint az összeomlás időszaka alatt. A GLM modellek alapján eredményeink azt mutatták, hogy a gyöngybagoly fészekalj méretét kizárólag a mezei pocok, mint fő zsákmány elérhetősége és fogyasztási aránya befolyásolta, míg más kisemlős zsákmánykategóriák nem voltak hatással a fészekalj méretre. Ezek az eredmények alátámasztották azt a megállapítást, hogy a szaporodásukat kora tavasszal megkezdő pocokfogyasztó ragadozó madarak és baglyok fészekalj mérete előrejelzi a kora tavaszi időszakban jellemző pocok abundanciát. 
A figyelembe vett egyéb kisemlős zsákmánycsoportok tekintetében csak az egérfélék zsákmánykategóriái (Apodemus spp., Muridae) esetén bizonyítottuk e csoportok alternatív zsákmány szerepét.

Kulcsszavak: reprodukciós kimenet, táplálékfogyasztás, alternatív zsákmány, gradáció

${ }^{1}$ University of Pécs, Faculty of Sciences, Institute of Biology, Department of Ecology, 7624 Pécs, Ifjúság utca 6., Hungary

${ }^{2}$ Baranya County Group of BirdLife Hungary, 7632 Pécs, Siklósi út 94., Hungary BirdLife Hungary, 1121 Budapest, Költö utca 21., Hungary

* corresponding author, e-mail: hgypte@gamma.ttk.pte.hu

\section{Introduction}

Raptors and owls show both numerical and functional responses depending on the variation of their food supply, particularly the density fluctuation of their main prey (Korpimäki \& Norrdahl 1989, 1991, Salamolard et al. 2000, Tome 2003, Reif et al. 2004, Millon \& Bretagnolle 2008, Tóth 2014, Baudrot et al. 2016). The reproductive output and population dynamics of these avian predators are strongly affected by multi-annual periodic (cyclic) or irregular fluctuation of small mammals, especially herbivorous voles (Korpimäki et al. 2002, Klok \& de Roos 2007, Pavluvčík et al. 2015, Zárybnická et al. 2015, Fay et al. 2020). Vole-eating raptors and owls show a rapid demographic response to the dramatically change of their main prey abundance, therefore, the breeding parameters of these diurnal and nocturnal birds of prey are considered as potential indicators to forecast the general abundance of voles (Solonen et al. 2015).

The Common Barn-owl was characterized as an opportunistic nocturnal raptor because it hunts various easily available prey species or groups depending on their density (Campbell et al. 1987, Taylor 1994, Bellocq 2000, Paspali et al. 2013, Charter et al. 2015). According to many studies, this owl species is a typical small mammal specialist (Marti 1988, Bonvicino \& Bezerra 2003, Charter et al. 2009), which was also confirmed by a recent biogeographical assessment of the cosmopolitan Common Barn-owl group's (Tyto alba species complex) trophic ecology at global scale (Romano et al. 2020). However, Barn Owls frequently select a given prey species and/or group, and based on their functional response, switch easily between prey items in their foraging strategy (Yom-Tov \& Wool 1997, Tores et al. 2005, Romano et al. 2020). According to the 'alternative prey hypothesis', if the main prey species declines in the given year, generalist predators can show dietary shifts and switch to alternative prey (Angelstam et al. 1984), which was detected in case of raptors (Reif et al. 2001, Riegert et al. 2009, Kreiderits et al. 2016, Dementavičius et al. 2020) and different owls (Korpimäki et al. 1990, Jędrzejewski et al. 1994, Sasvári et al. 2000, Riegert et al. 2009), including also the Common Barn-owl (Roulin 2004a, Tores et al. 2005, Charter et al. 2015, Baudrot et al. 2016).

In temperate ecosystems, Bernard et al. (2010) reported how the dietary response of Common Barn-owl can be affected by the density of prey species and demonstrated that the frequency of a given prey in the diet depends also on the population density or availability of other species. The feeding behaviour of Barn Owls is generally opportunistic (Bernard et al. 2010), but complex patterns of prey selection with switching mechanism to alternative 
prey were reported by studies particularly in arid environments, where food intake results supported that the Common Barn-owl is a rather selective opportunistic predator (Heywood \& Pavey 2002, Tores et al. 2005, McDowell \& Medlin 2009, Romano et al. 2020).

The food consumption of the Common Barn-owl is mainly determined by changes in the density of agricultural pest rodents such as different Microtus vole species, both in temperate zones of Nearctic and Paleartic regions and the Mediterranean (Colvin \& MacLean 1986, Marti 1988, Taylor 1994, Shehab \& Al Charabi 2006, Charter et al. 2009, Kitowski 2013, Petrovici et al. 2013, Purger 2014, Veselovský et al. 2017). Due to their preference and high rates of consumption, several studies demonstrated negative correlation between vole (Microtus spp.) frequency and food-niche breadth of the Common Barn-owl (Milchev et al. 2006, Marti 2010, Hindmarch \& Elliott 2015, Milchev 2015, Horváth et al. 2018). As vole specialists, the breeding success of Barn Owls increases with the proportion of voles (Microtus spp.) in the diet (Gubanyi et al. 1992, De Bruijn 1994, Taylor 1994, Klok \& de Roos 2007, Bernard et al. 2010, Charter et al. 2018).

Considering the European agricultural landscape, the Common Vole (Microtus arvalis Pallas, 1778) is the most abundant and widespread microtine rodent species, and due to high overshoots of carrying capacity (Bryja et al. 2001, Jacob \& Tkadlec 2010), Common Voles cause significant damage during outbreaks (Lambin et al. 2006, Jacob et al. 2014, 2020). Population dynamics of the Common Vole is characterized by multiannual fluctuation with 3-5 year-long population cycles in agricultural fields (Tkadlec \& Stenseth 2001, Lambin et al. 2006, Cornulier et al. 2013, Luque-Larena et al. 2013, Jacob et al. 2014, 2020) and it shows typical well-defined and separable demographical phases, such as long intervals of low abundance (crash phase), increase phase and short intervals of peak phase (outbreak) (Tkadlec \& Stenseth 2001, Lambin et al. 2006).

Earlier studies of the Common Barn-owl's breeding biology had already reported that the reproductive output of owls were larger in the peak phase during the outbreak than in the non-outbreak periods of the Common Vole (Schönfeld \& Girbig 1975, Kaus 1977, Baudvin 1979, De Bruijn 1994). These results suggested that population fluctuation of Common Barn-owls correlated with changes of vole density. Klok and de Roos (2007) demonstrated that the fluctuating change in the breeding success of the Common Barn-owl correlated with the dynamics of voles as main prey. Based on the analysis of the vole fluctuation effect in a simple predator-prey model system, this study suggested that population persistence of the Common Barn-owl is affected by poor-years with low abundance of voles (Klok \& de Roos 2007). Furthermore, the increase in productivity of Common Barn-owls was demonstrated in the Czech Republic, which study confirmed a significant linear relationship between the annual productivity and Common Vole abundance (Pavluvčík et al. 2015).

Size-dependent predation of the Common Barn-owl was reported and discussed in more studies (Kotler et al. 1988, Yom-Tov \& Wool 1997, Bellocq 1998), which confirmed that the prey size is an important trait of the profitability (Ille 1991). Therefore, we hypothesized that large body mass rodent (LBMR) species, such as European Water Vole (Arvicola amphibius), Brown Rat (Rattus norvegicus) and Black Rat (R. rattus) may be a possible alternative prey group for the Barn Owls to compensate for the lack and/or lower availability of the main prey species, especially during its crash phase. In addition, considering the importance 
of the Common Vole as main prey abundance, we predicted that the reproductive output of the Barn Owl reaches its maximum in the peak phase.

According to the above predictions, the present study aims to examine the differences in reproductive output and food intake of the Common Barn-owl among the demographic phases of the Common Vole as main prey (1) and to analyse the relationships between the consumption rate of the main or potential alternative prey categories and variation of the owls' breeding parameters between two vole outbreaks (2).

\section{Material and methods}

\section{Study area and sample collection}

The study was conducted in the south-eastern part of the Transdanubian region in Southern Hungary, in Baranya County $\left(4,429.6 \mathrm{~km}^{2}\right)\left(45^{\circ} 53^{\prime} \mathrm{N}, 18^{\circ} 20^{\prime} \mathrm{E}\right)$ (Figure 1). Due to significant Mediterranean and sub-Mediterranean climate effects, the environmental conditions of this county are favourable for Common Barn-owls. Moreover, the county is characterized by a large number of villages (number of settlements is 301), and four mesoregions are distinguished in the total area of Baranya. However, the largest territorial coverage of the county is represented by two mesoregions: the Drava floodplain (DFP) and the Mecsek and TolnaBaranya hill country (MTBHC). The area of the Drava floodplain includes the erstwhile flood basin of the Drava, altitude varies between 89 and 212 meters, its area size is 1,300

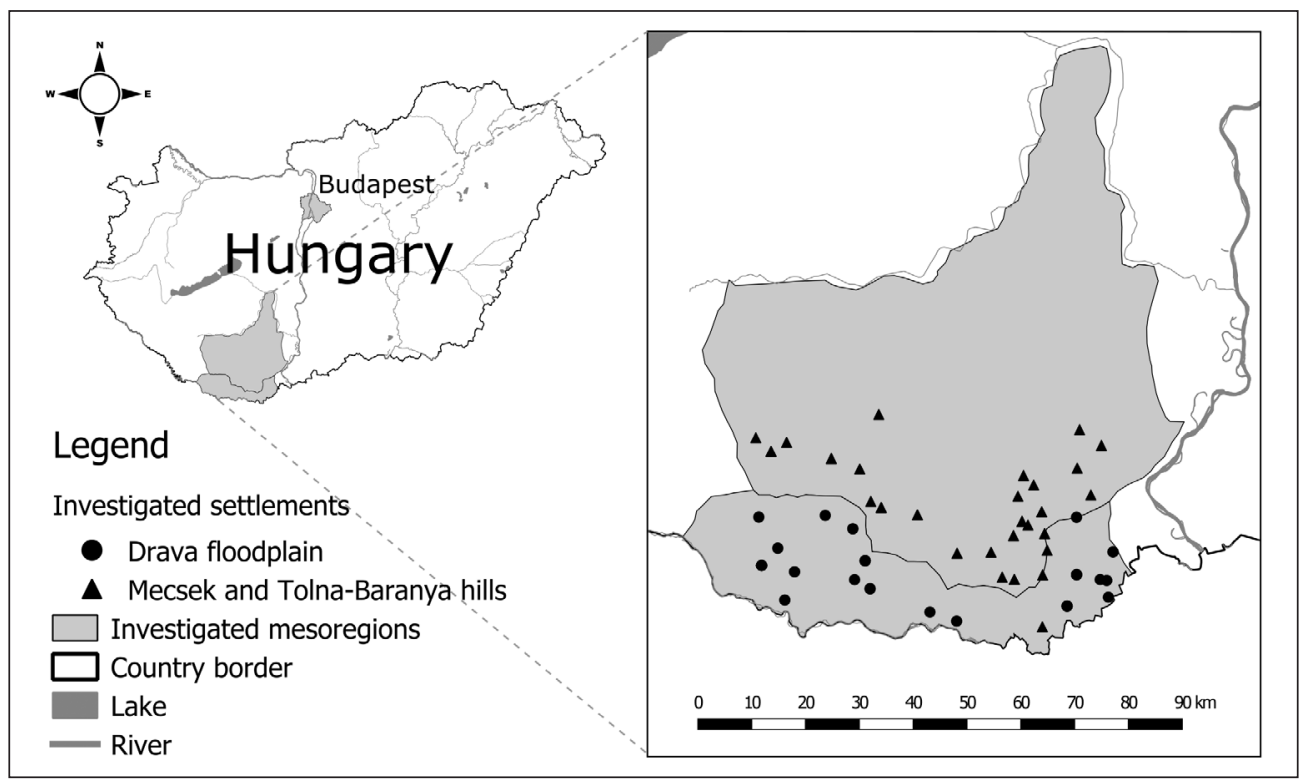

Figure 1. Study area in the South-Transdanubian region, Hungary, showing the location of the two mesoregions and the investigated nesting pairs within the examined landscape

1. ábra A vizsgált terület Dél-Dunántúlon, Magyarországon, feltűntetve a két középtáj és a vizsgált költőpárok elhelyezkedését a vizsgált tájegységen belül 
$\mathrm{km}^{2}$. The climate of this mesoregion is moderately warm and moderately humid. The number of sunny hours increases from west $(2,000)$ to east $(2,080)$, while the annual amount of precipitation increases from east to west: $630-680 \mathrm{~mm}$ in the east, while more than $720 \mathrm{~mm}$ in the west. The Mecsek and Tolna-Baranya hill country is situated north of the previous mesoregion and its area is $4,400 \mathrm{~km}^{2}$. The number of sunny hours is between 1,400 and 1,450 , and yearly mean precipitation is $680-720 \mathrm{~mm}$. The Mediterranean climatic impact is typical in both regions. Due to different environmental conditions, these two landscapes were considered as explanatory variables for our analysis.

In the present study, data on the reproductive output come from the long-term monitoring program of nest box breeding Common Barn-owls. The continuous survey of the reproductive parameters has been conducted since the mid-90s in our studied region by the Baranya County Group of BirdLife Hungary during the last 25 years (Bank et al. 2019). Detailed data of nest box installation and control protocol can be found in Bank et al. (2019). Pellet collections and diet analyses were also conducted parallel to the breeding biology monitoring.

For the analysis, we used data from 2015 to 2019, a time period which represented a full demographic cycle of the Common Vole after the 2014 outbreak with an exceptionally high peak (see Luque-Larena et al. 2015, Rodríguez-Pastor et al. 2017 in Spain, plant protection engineers personal communication of Bóly Co.'s crop production sector in Hungary) and included the crash (2015-2016), the increase (2017-2018) and the peak (outbreak) (2019) phase. The 2019 peak phase indicated a pan-European synchronous population outbreak of the Common Vole (Jacob et al. 2020). Considering the years, the mesoregions, the first and second annual clutches and the presence/absence of pellet collection per nesting site, a stratified random procedure of sample selection was used to ensure a proportionate sampling effort in the 5-year period. Because the number of successful second clutches was low for randomly selected pairs, only the data of the first clutches were considered in the analysis. From the total of 389 clutches, where the complete reproductive history was known, 81 first clutches $(\mathrm{N}=30$ in crash phase, $\mathrm{N}=30$ in increase phase and $\mathrm{N}=21$ in peak phase) were taken into account for the analysis. The average number of first clutches per year was 16.2 $\pm 2.45 \mathrm{SE}$ (range: 9-21). The randomly selected sample consisted of data from 46 different localities (settlements) and 53 nest boxes.

Pellets were processed by the dry technique, the individual pellets were broken down by hand and prey items were identified to the lowest possible taxonomical level. Small mammals were identified based on skeletal parameters (features of skull, mandible and teeth; März 1972, Yalden 1977, Yalden \& Morris 1990). Three different Apodemus species, the Wood Mouse (Apodemus sylvaticus), the Yellow-necked Wood Mouse (A. flavicollis) and the Pygmy Field Mouse (A. uralensis) were categorized commonly as Apodemus spp. When the Striped Field Mouse (A. agrarius) was not separable from the Sylvaemus group (Apodemus spp.) the individuals were determined as 'unidentifed Apodemus'. The sibling species of the genus Mus were determined according to Macholán (1996) and Kryštufek \& Macholán (1998). Birds were identified by their skulls, bills, feet, pelvises and feathers, and frogs (Anura) by their skulls and bones of the postcranial skeleton. Prey items were identified to genus (small mammals, birds), to order (frogs), and to class (birds) level if major skeletal elements were missing. 


\section{Data analysis}

For each of the selected Barn Owl pairs, the reproductive output was evaluated by six parameters: 1) clutch size (number of eggs in a clutch), 2) brood size at hatching, 3) brood size at fledging, 4) hatching success (the percentage of eggs that hatched within each clutch), 5) fledging success (the percentage of young that fledged from each brood), and 6) reproductive success (the percentage of fledged young per eggs from each successful nest) (see Bank et al. 2019).

Considering the food consumption of the owls, we focused our analysis on small mammal prey taxa ( $98.75 \%$ of prey MNI - 9,966 out of 10,092 prey specimens). Prey numbers were estimated as the minimum number of individuals (MNI) which we determined based on the same anatomical parts of bones for small mammals (McDowell \& Medlin 2009, Torre et al. 2015, Tulis et al. 2015). The percent frequency of occurrence (MNI \%) was calculated for the total number of prey at the prey species and group level found in the pellet sample of each nesting pair.

To analyse the relationship between the breeding performance and diet composition of Common Barn-owls the following prey categories of small mammals were considered: Common Vole (M. arvalis) (Mar) as main prey species, Lesser White-toothed Shrew (Crocidura suaveolens) (Csu), Bicolored White-toothed Shrew (Crocidura leucodon) (Cle) and Striped Field Mouse (A. agrarius) (Aag) at species level, Sorex, Crocidura, Apodemus spp. (excluding the Striped Field Mouse) at genus level, and Soricidae, Muridae at the highest taxonomic level as possible alternative prey categories. In addition, the cumulative proportion of large body mass rodent (LBMR) species and Shannon diversity (H') of prey composition were calculated and used as predictors in our analysis.

In the first step, breeding parameters and derived percentage values of successes, as well as the proportion (MMI\%) of the prey categories were presented as range and mean \pm SE per breeding pair for the total sample and sample groups based on demographic phases of the Common Vole and the two mesoregions, respectively. After analysis of normality by Shapiro-Wilk test (Zar 2010), nonparametric statistics were used to evaluate the results. Boxplots (median, 25-75\% percentiles and min-max values) were used to present the variation of the Barn Owls' reproductive output and their small mammal consumption. Mann-Whitney's U-test and Kruskal-Wallis test (followed by Dunn's post hoc test for multiple comparisons) were used to compare the values of breeding parameters and relative abundances (MMI\%), as well as Shannon diversity (H') of prey composition between the two mesoregions and among the demographic phases of Common Vole, respectively (Zar 2010).

Second, we tested the impact of prey abundance $\left(\right.$ Prey $\left._{\mathrm{i}}\right)$ and prey diversity (H') as continuous predictors as well as the Common Vole's demographic phase (Phase) and the mesoregion (Region) as categorical explanatory variables on the reproductive outputs as response variables ( $\mathrm{Y}_{\mathrm{i}}$ ) using Generalized Linear Models (GLM). Based on the interaction of predictors, three models were built in case of each breeding parameters of the Common Barn-

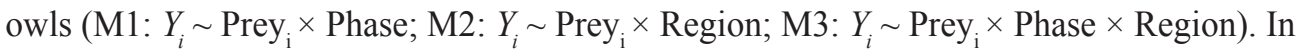
case of count data (clutch and brood size, number of fledglings), a quasi-Poisson error distribution with a log-link function was used to correct for overdispersion from a standard 
Poisson distribution (Zuur et al. 2009), while in case of breeding successes as derived percentage data a quasi-binomial error distribution with logit-link function was used for analysis. In case of both error distributions, 'glm()' function and "lme4" packages (Bates et al. 2015) were used to build the GLM models. Functions from the packages 'AER' (Kleiber \& Zeileis 2008, 2009) and 'DHARMa' (Hartig 2017) were used to test for overdispersion. To rank and evaluate the importance of candidate models, a Quasi-Akaike Information Criteria with a correction for small sample sizes (QAICc) was used. The lowest QAICc value was assigned to the best-approximating model, in addition, models with $\triangle$ QAICc $<2$ were also considered to have significant support (Burnham \& Anderson 2002). Akaike model weights $\left(w_{i}\right)$ were included to represent the probability of best fit among all candidate models (Burnham \& Anderson 2002). The package "MuMIn" (Barton 2016) was used to implement the model selection. Analysis of deviance table (Likelihood Ratio (LR) $\chi^{2}$ for Type III analysis) was used to test the effect of predictors and their interactions (Dobson \& Barnett 2018), and the results of the fitted regression models were visualized in the package 'effects' (Fox et al. 2017). All statistical analyses were conducted in the $\mathrm{R}$ version 3.4.0 environment ( $\mathrm{R}$ Core Team 2019). Statistical tests were considered significant at the level $P \leq 0.05$ in all analyses (Sokal \& Rohlf 1997).

\section{Results}

Regarding the breeding parameters of the investigated first clutches, the average number of eggs was $6.91 \pm 0.15$ (range 4-12), the mean number of hatchlings was $5.91 \pm 0.20$ (range $0-10$ ) and the average number of fledglings was $4.26 \pm 0.21$ (range $0-9$ ) in the 5 studied years. The clutch size (Kruskal-Wallis test: $H(2, \mathrm{~N}=81)=1.28$, n.s.) and the brood size did not differ $(H(2, \mathrm{~N}=81)=3.29$, n.s. $)$, while the number of fledglings significantly varied among the demographic phases of the Common Vole (Kruskal-Wallis test: $H(2, \mathrm{~N}=81)=$ $10.52, P=0.0066)$. The number of fledglings was significantly higher in the increase phase than during the crash phase (post hoc Dunn test: $z=3.004, P=0.0079$ ) (Figure 2a). Considering the breeding successes, the mean of hatching success was $86.29 \pm 2.36 \%$ (range $0-100 \%$ ), the mean of fledging success was $70.19 \pm 3.13 \%$ (range $0-100 \%$ ) and the reproductive success was $62.81 \pm 2.98 \%$ (range $0-100 \%$ ) during the total demographic cycle of the Common Vole. We did not find significant difference in hatching success $(H(2, \mathrm{~N}=81)$ $=5.58$, n.s. $)$, however, the fledging $(H(2, \mathrm{~N}=81)=7.42, P=0.0244)$ and the reproductive success $(H(2, \mathrm{~N}=81)=9.83, P=0.0073)$ significantly varied among the vole phases. In both cases, the success was significantly higher during the increase than in the crash phase of the Common Vole (post hoc Dunn test - fledging success: $z=2.61, P=0.0027$; breeding success: $z=3.12, P=0.0054$ ), similar to the number of fledglings (Figure $2 b$ ). Based on the statistical analysis of overall data, the value of breeding parameters (Mann-Whitney U-test: $Z=1.05-0.26$, n.s. $)$ and successes $(Z=0.67-1.73$, n.s. $)$ did not show significant difference between the two mesoregions. As evaluated based on demographic phases of the Common Vole, the number of fledglings (Mann-Whitney U-test: $Z=2.37, P=0.017$ ) and the reproductive success $(Z=2.27, P=0.022)$ differed significantly only in the increase phase, while 


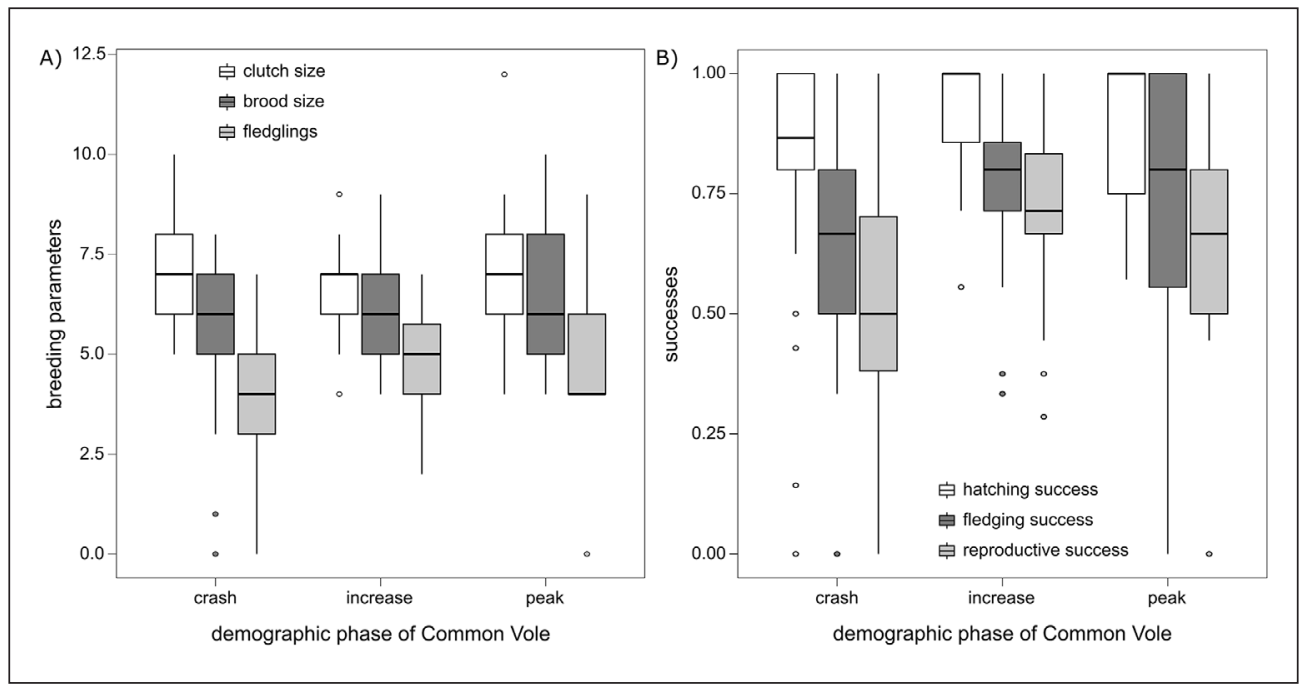

Figure 2. Variation in the values of breeding parameters (A) and breeding biology successes (B) (median, 25-75\% percentiles, min-max) in the demographic phases of Common Vole

2. ábra A költési paraméterek (A) és sikerek (B) értékeinek (medián, 25-75\% percentilis, minimummaximum) változása a mezei pocok demográfiai fázisaiban

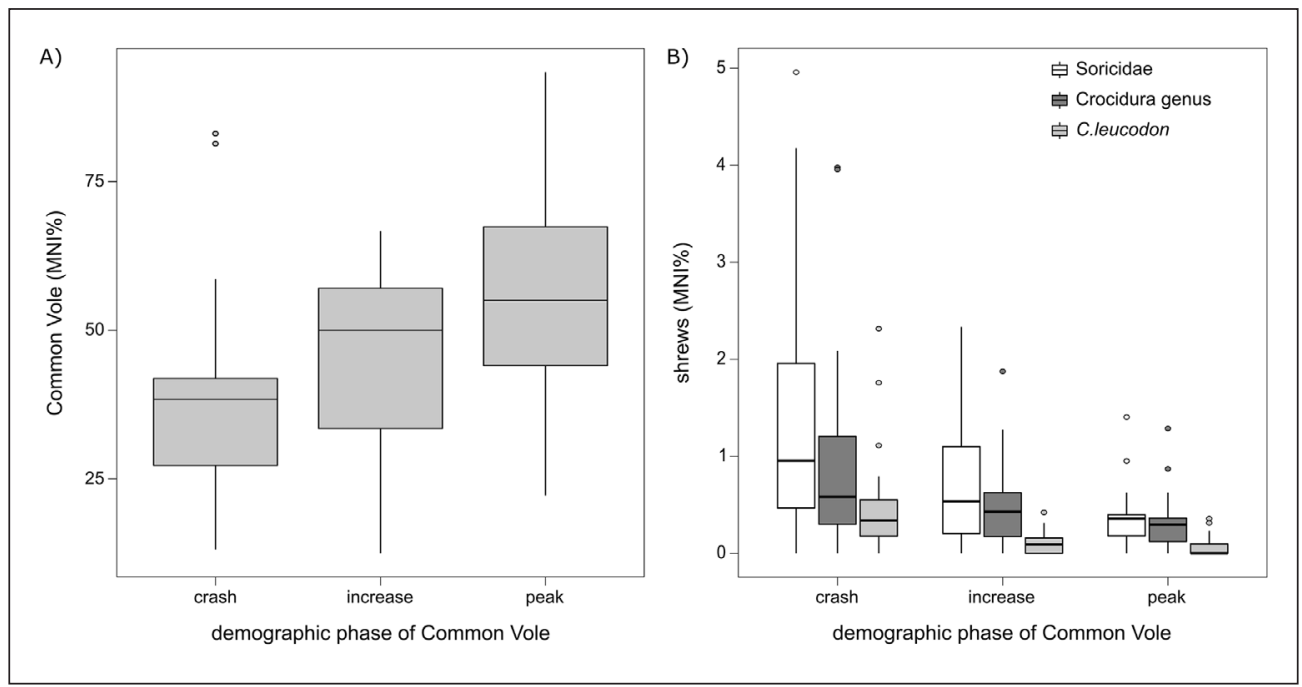

Figure 3. Variation in the relative abundance of Common Vole (A) and shrews (B) (median, $25-75 \%$ percentiles, min-max) in the demographic phases of Common Vole

3. ábra A mezei pocok (A) és a cickányok (B) gyakorisági értékeinek (medián, 25-75\% percentilis, minimum-maximum) változása a mezei pocok demográfiai fázisaiban 
for the other two demographic phases showed no significant differences in the reproductive output values between the two mesoregions.

Considering the small mammal prey categories, the mean of Common Vole's relative abundance (MNI \%) in the food was $44.94 \pm 1.97 \%$ (range 12.5-93.37\%) for its whole demographic cycle. The proportion of this main prey significantly varied among the demographic phases $(H(2$, $\mathrm{N}=81)=15.29, P=0.0005)$. The prey consumption data of Common Barn-owls reflected that the MNI \% of this $r$-strategist prey was significantly higher during the peak than in the crash phase (post hoc Dunn test: $z=3.88, P<0.0003$ ), but in the other two pairings of demographic phases there was no significant difference (post hoc Dunn test: $z=1.88-2.2$, n.s.) (Figure 3a). Due to the high range overlap of the Common Vole's consumption rate in its whole demographic cycle, the relative abundance (DFP: $=45.45 \pm 2.64 \%$, range: $14.81-93.37 \%$; MTBHC: $=$ $44.34 \pm 2.98 \%$, range: $12.5-83.05 \%$ ) did not differ between the two mesoregions (Mann-Whitney U-test: $\mathrm{Z}=0.27$, n.s.). As regards the relative abundance of potential alternative prey categories and prey diversity for the whole 5-year period, the mean $\pm \mathrm{SE}$ and range values per breeding pair are summarized in Table 1. Larger proportion values (MMI \%) were detected in case of some potential alternative prey categories, such as Muridae, Apodemus spp. Soricidae, Crocidura and Bicolored White-toothed Shrew (C. leucodon) (in descending order). However, significant differences of the relative abundances among the demographic phases of the Common Vole were only detected in case of the three shrew categories (Soricidae: Kruskal-Wallis test: $H(2, \mathrm{~N}=81)=13.66, P=0.0011$; Crocidura: $H(2, \mathrm{~N}=81)=9.75$, $P=0.0076 ;$ C. leucodon: $H(2, \mathrm{~N}=81)$ $=31.16, P<0.0001)$. The total abundance of shrews (Soricidae) and the Crocidura genus were higher in the crash phase than during the outbreak (post hoc Dunn test: $z=2.98-3.60$, $P<0.01$ ), while the proportion of consumption of the Bicolored Whitetoothed Shrew was higher in the collapse $(z=4.99, P<0.0001)$ and increase phase $(z=4.27, P<0.0001)$ than in the peak phase (Figure $3 b$ ). Distribution of means $( \pm \mathrm{SE})$ and the range intervals of the relative abundances (MMI \%) from the total dataset are summarized in comparison of the two mesoregions (Table 2). Although the rate of consumption of each prey category varied in a different range of percent values in the owls' diet, we did not find significant differences between the two mesoregions

Table 1. Average values ( $\pm \mathrm{SE}$, range) of the potential alternative prey categories> proportion (MMI $\%)$, prey diversity for the whole 5-year dataset

1. táblázat A potenciális alternatív zsákmány kategóriák arányának (MMI \%), valamint a zsákmány diverzitás átlaga ( $\pm \mathrm{SE}$, Min-Max) a teljes 5 éves adatkészletből

\begin{tabular}{|l|r|r|c|}
\hline $\begin{array}{c}\text { Prey categories/ } \\
\text { Shannon } \mathbf{H}^{\prime}\end{array}$ & Mean () & \pm SE & Range \\
\hline Species level & & & \\
\hline Crocidura suaveolens & 4.90 & 0.98 & $0-21.98$ \\
\hline Crocidura leucodon & 4.68 & 0.92 & $0-23.16$ \\
\hline Apodemus agrarius & 7.49 & 0.58 & $1.69-13.57$ \\
\hline Genus level & & & \\
\hline Sorex & 1.29 & 0.32 & $0-6.67$ \\
\hline Crocidura & 9.59 & 1.79 & $0-39.78$ \\
\hline Apodemus spp. & 22.62 & 2.98 & $4.39-45.38$ \\
\hline Higher taxa & & & \\
\hline Soricidae & 13.22 & 2.11 & $0-49.59$ \\
\hline Muridae & 43.98 & 2.91 & $15.25-77.33$ \\
\hline LBMR* & 3.74 & 0.87 & $0-21.05$ \\
\hline Shannon diversity $\left(\mathrm{H}^{\prime}\right)$ & 1.82 & 0.07 & $0.72-2.51$ \\
\hline
\end{tabular}

*: LBMR: large body mass rodents / nagy testtömegű rágcsálók 
Table 2. Average value ( $\pm \mathrm{SE}$, range) of the potential alternative prey categories' proportion (MMI\%), prey diversity according to mesoregions for the whole 5-year dataset

2. táblázat A potenciális alternatív zsákmány kategóriák arányának (MMI\%), valamint a zsákmány diverzitás átlaga ( \pm SE, Min-Max) a középtájak bontásában a teljes 5 éves adatkészletből

\begin{tabular}{|l|c|c|c|c|c|c|}
\hline \multirow{2}{*}{$\begin{array}{c}\text { Prey categories/ } \\
\text { Shannon H' }\end{array}$} & \multicolumn{3}{|c|}{$\begin{array}{c}\text { Drava floodplain (DFP) } \\
\text { (N=44) }\end{array}$} & \multicolumn{2}{c|}{$\begin{array}{c}\text { Mecsek and Tolna-Baranya hill } \\
\text { country (MTBHC) (N = 37) }\end{array}$} \\
\cline { 2 - 7 } & Mean () & $\mathbf{\pm S E}$ & \multicolumn{1}{|c|}{ Range } & Mean () & \pm SE & Range \\
\hline Species level & & & & & & \\
\hline Crocidura suaveolens & 4.35 & 0.64 & $0-7.14$ & 3.56 & 0.79 & $0-21.99$ \\
\hline Crocidura leucodon & 2.37 & 0.61 & $0-23.16$ & 2.15 & 0.52 & $0-17.58$ \\
\hline Apodemus agrarius & 8.65 & 0.74 & $0-25$ & 7.38 & 0.84 & $0-25$ \\
\hline Genus level & & & & & & \\
\hline Crocidura & 6.72 & 1.11 & $0-39.78$ & 5.72 & 1.16 & $0-39.56$ \\
\hline Apodemus spp. & 21.69 & 1.49 & $2.41-41.15$ & 25.39 & 2.11 & $4.39-59.26$ \\
\hline Higher taxa & & & & & & \\
\hline Soricidae & 9.05 & 1.41 & $0-49.59$ & 8.21 & 1.44 & $0-41.76$ \\
\hline Muridae & 40.02 & 2.22 & $4.82-71.61$ & 43.23 & 2.64 & $12.5-77.33$ \\
\hline LBMR* & 2.81 & 0.59 & $0-21.05$ & 2.99 & 0.77 & $0-25$ \\
\hline Shannon diversity $\left(\mathrm{H}^{\prime}\right)$ & 1.62 & 0.07 & $0.34-2.51$ & 1.53 & 0.07 & $0.72-2.43$ \\
\hline
\end{tabular}

*: LBMR: large body mass rodents / nagy testtömegü rágcsálók

neither in proportion of prey categories (Mann-Whitney U-test: $\mathrm{Z}=0.21-1.31$, n.s.), nor in Shannon diversity $(Z=0.97$, n.s.) values. Difference of alternative prey abundance and Shannon H' were tested between the two mesoregions in case of each demographic phase of the Common Vole. Significant differences were detected in case of four alternative prey categories and the Shannon H' during the crash phase of the Common Vole (Table 3). In contrast, we did not find significant differences between the two regions in the increase and the peak phase.

As regards the GLM analysis, clutch size was affected by the abundance of the Common Vole as the main prey. Based on model selection parameters, M2 was the best approximating model (Table 4), the result of which showed the significant main effect of vole proportion $\left(\chi^{2}=4.22\right.$, $P=0.04)$, while the mesoregion and the

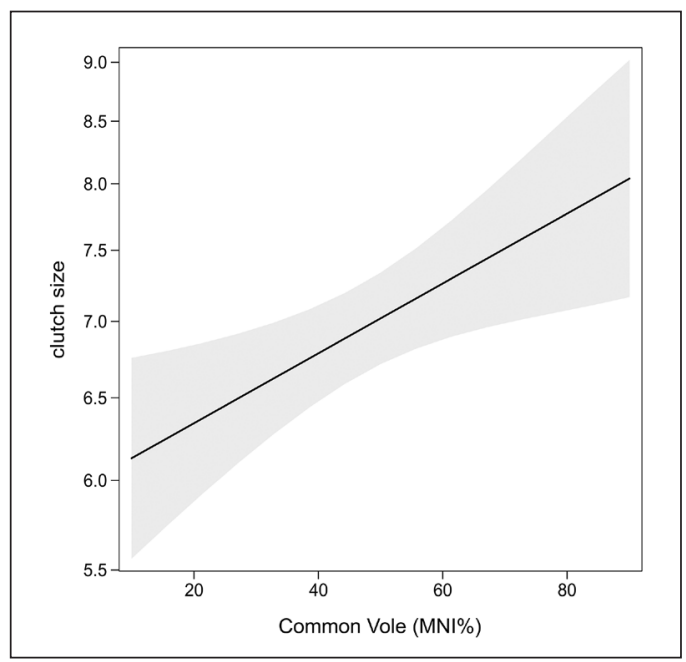

Figure 4. Relationship between clutch size and relative abundance of the Common Vole (M. arvalis) based on main effect of the M2 model

4. ábra A fészekalj méret és a mezei pocok relatív abundancia közötti összefüggés az M2 modell főhatása alapján 
Table 3. Results of alternative prey abundance analysis (Mann-Whitney $U$ test) in comparison of the two mesoregions (DFP vs TBHC) during the crash phase of the Common Vole

3. táblázat Az alternatív zsákmány abundancia elemzés eredménye (Mann-Whitney $U$ teszt) a két középtáj (DFP vs TBHC) összehasonlításában a mezei pocok összeomlási fázisában

interaction of these two predictors were not determining factors of clutch size. Considering the estimation of regression coefficient, the consumption rate of the Common Vole positively affected the clutch size (Table 5, Figure 4).

Brood size was affected by the proportion of the Common Vole and the Shannon diversity based on the best-fitted M2

\begin{tabular}{|l|r|r|r|}
\hline \multicolumn{1}{|c|}{$\begin{array}{c}\text { Prey categories/ } \\
\text { Shannon H' }\end{array}$} & $\boldsymbol{U}$ & $\boldsymbol{Z}$ & $\boldsymbol{P}$ value \\
\hline Species level & & & \\
\hline Crocidura suaveolens & 50 & 2.56 & $<0.05$ \\
\hline Crocidura leucodon & 90 & 0.89 & n.s. \\
\hline Apodemus agrarius & 105 & 0.27 & n.s. \\
\hline Genus level & & & \\
\hline Sorex & 49 & 2.59 & $<0.01$ \\
\hline Crocidura & 60 & 2.14 & $<0.05$ \\
\hline Apodemus spp. & 99 & 0.52 & $n . s$. \\
\hline Higher taxa & & & \\
\hline Soricidae & 50 & 2.56 & $<0.05$ \\
\hline Muridae & 101 & 0.44 & $n . s$. \\
\hline LBMR & 84 & 1.14 & n.s. \\
\hline Shannon diversity $\left(\mathrm{H}^{\prime}\right)$ & 29 & 3.43 & $<0.001$ \\
\hline
\end{tabular}

*: LBMR: large body mass rodents / nagy testtömegű rágcsálók model (Table 4). In case of each three continuous predictors, the significant main effect was confirmed by Type III test (Mar: $\chi^{2}=$ $\left.6.51, P=0.0108 ; H^{\prime}: \chi^{2}=8.73, P=0.0031\right)$. Similar to clutch size, significant positive relationships were confirmed by the estimated parameters between brood size and the relative abundance (MNI\%) of the Common Vole (Table 5, Figure $5 a$ ). In contrast, a significant negative regression was detected between the prey diversity and the brood size (Table 5,

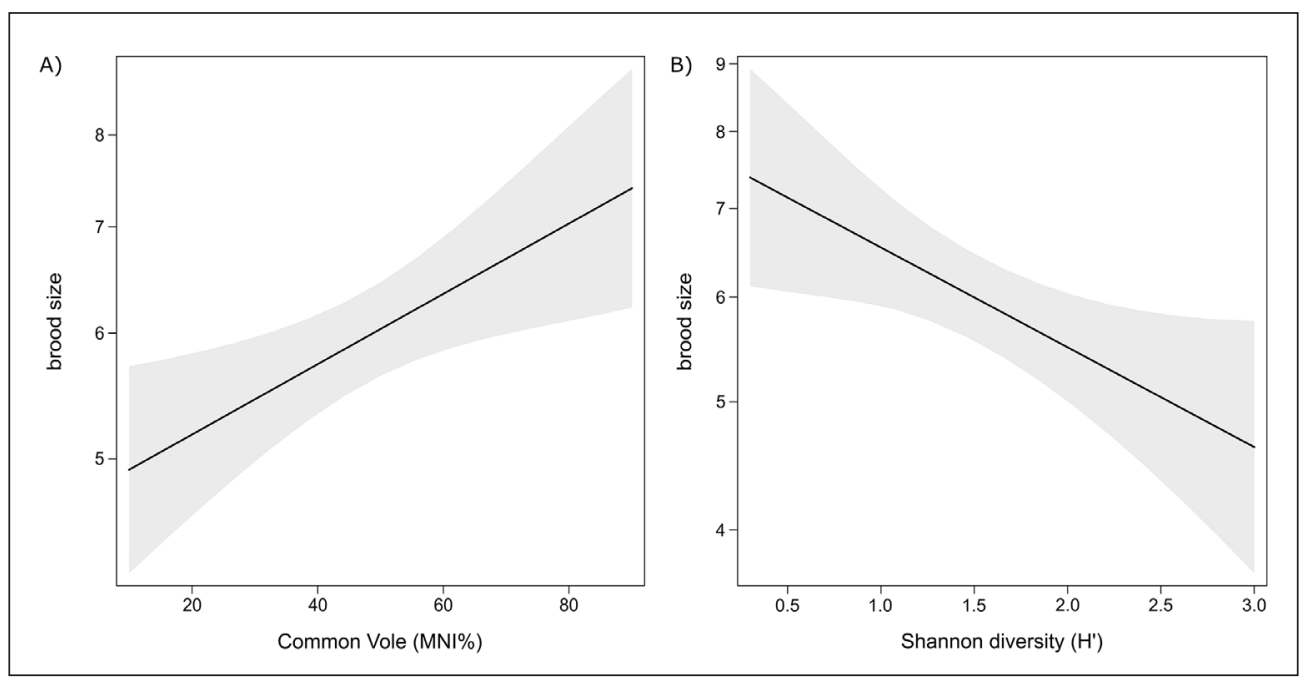

Figure 5. Relationship between brood size and relative abundance of the Common Vole (M. arvalis) (A) and Shannon diversity (B) based on main effects of the M2 model

5. ábra A fészekalj méret és a mezei pocok relatív abundancia (A), valamint a Shannon diverzitás (B) közötti összefüggés az M2 modell főhatásai alapján 
Table 4. Quasi-Akaike's rank value of the candidate GLM models with count breeding parameters (For the abbreviations of the predictor variables see Material and Methods)

4. táblázat Az alkalmazott modellek Quasi-Akaike's rang értékei a számolt szaporodási paraméterek esetén (A magyarázó változók rövidítését lásd a Material and Methods fejezetben)

\begin{tabular}{|c|c|c|c|}
\hline$Y_{i} /$ Predictor/Model (ID) & QAICc & $\Delta_{\mathrm{i}}$ & $w_{i}$ \\
\hline \multicolumn{4}{|l|}{ clutch size } \\
\hline \multicolumn{4}{|l|}{ Microtus arvalis } \\
\hline$\sim$ Mar $\times$ Region (M2) & 334.2 & 0.00 & 0.806 \\
\hline$\sim " \times$ Phase $(\mathrm{M} 1)$ & 337.1 & 2.85 & 0.194 \\
\hline$\sim " \quad \times$ Phase $\times$ Region (M3) & 348.8 & 14.54 & 0.001 \\
\hline \multicolumn{4}{|l|}{ brood size } \\
\hline \multicolumn{4}{|l|}{ Microtus arvalis } \\
\hline$\sim$ Mar $\times$ Region (M2) & 347.9 & 0.00 & 0.685 \\
\hline$\sim " \times$ Phase $(\mathrm{M} 1)$ & 349.5 & 1.55 & 0.314 \\
\hline$\sim " \quad \times$ Phase $\times$ Region (M3) & 360.5 & 12.63 & 0.001 \\
\hline \multicolumn{4}{|l|}{ Apodemus spp. } \\
\hline$\sim$ Asp $\times$ Phase $(\mathrm{M} 1)$ & 349.1 & 0.00 & 0.807 \\
\hline$\sim " \times$ Region $(\mathrm{M} 2)$ & 351.9 & 2.89 & 0.191 \\
\hline$\sim$ “ $\times$ Phase $\times$ Region (M3) & 360.3 & 11.25 & 0.003 \\
\hline \multicolumn{4}{|l|}{ Muridae } \\
\hline$\sim$ Muridae $\times$ Phase $(\mathrm{M} 1)$ & 349.3 & 0.00 & 0.726 \\
\hline$\sim \quad " \quad \times$ Region $(\mathrm{M} 2)$ & 351.3 & 1.96 & 0.272 \\
\hline$\sim$ “ $\quad \times$ Phase $\times$ Region M3) & 360.5 & 11.18 & 0.003 \\
\hline \multicolumn{4}{|l|}{ Shannon diversity $\left(\mathrm{H}^{\prime}\right)$} \\
\hline$\sim \mathrm{H}^{\prime} \times$ Region (M2) & 347.4 & 0.00 & 0.821 \\
\hline$\sim$ " $\times$ Phase (M1) & 350.5 & 3.05 & 0.179 \\
\hline$\sim$ " $\times$ Phase $\times$ Region (M3) & 361.1 & 13.66 & 0.001 \\
\hline \multicolumn{4}{|l|}{ number of fledglings } \\
\hline \multicolumn{4}{|l|}{ Microtus arvalis } \\
\hline$\sim$ Mar $\times$ Region $(\mathrm{M} 2)$ & 340.2 & 0.00 & 0.724 \\
\hline$\sim " \quad \times$ Phase (M1) & 342.2 & 2.01 & 0.265 \\
\hline$\sim " \times$ Phase $\times$ Region (M3) & 348.6 & 8.43 & 0.011 \\
\hline \multicolumn{4}{|l|}{ Shannon diversity $\left(\mathrm{H}^{\prime}\right)$} \\
\hline$\sim \mathrm{H}^{\prime} \times$ Region $(\mathrm{M} 2)$ & 340.5 & 0.00 & 0.701 \\
\hline$\sim$ " $\times$ Phase $(\mathrm{M} 1)$ & 342.8 & 2.35 & 0.217 \\
\hline$\sim$ " $\times$ Phase $\times$ Region (M3) & 344.8 & 4.30 & 0.082 \\
\hline \multicolumn{4}{|l|}{ LBMR } \\
\hline$\sim$ LBMR $\times$ Phase $(\mathrm{M} 1)$ & 337.6 & 0.00 & 0.950 \\
\hline$\sim \quad$ “ $\times$ Phase $\times$ Region M3) & 344.0 & 6.41 & 0.039 \\
\hline$\sim \quad$ " $\times$ Region (M2) & 346.6 & 8.92 & 0.011 \\
\hline
\end{tabular}

QAICc: Quasi-Akaike Information Criterion corrected for small sample size

$\triangle$ : QAICc differences

$w_{i}$ : Akaike weights 
Figure 5b). In addition, the brood size at hatching was influenced by the proportion of Apodemus spp. and total MNI\% of Muridae, as alternative prey categories of the Common Barnowl. The effect of both variables (Asp: $\chi^{2}=6.12, P=0.0134$; Phase: $\chi^{2}=13.1, P=0.0014$ ) and their interaction $\left(\chi^{2}=7.86, P=0.0196\right)$ of the best supported M1 model were significant (Table 4). Based on the interaction of model variables, the consumption of Apodemus spp. significantly affected the brood size during the crash phase of the Common Vole, while the relationship between the proportion of this prey and the number of nestlings was significantly negative in the peak phase and a weak negative relation was typical during the increase phase (Table 5, Figure 6a). A slight positive linear regression of the main effect of wood mice (Apodemus spp.) was indicated by the significant estimated parameter (Table 5). The obtained results were similar also in case of the total proportion of Muridae. Based on the analysis of deviance table of the best-fitted M1 model (Table 4), the effect of Phase $\left(\chi^{2}=9.58, P=0.0083\right)$ and Muridae $\times$ Phase interaction $\left(\chi^{2}=6.05, P=0.0485\right)$ were

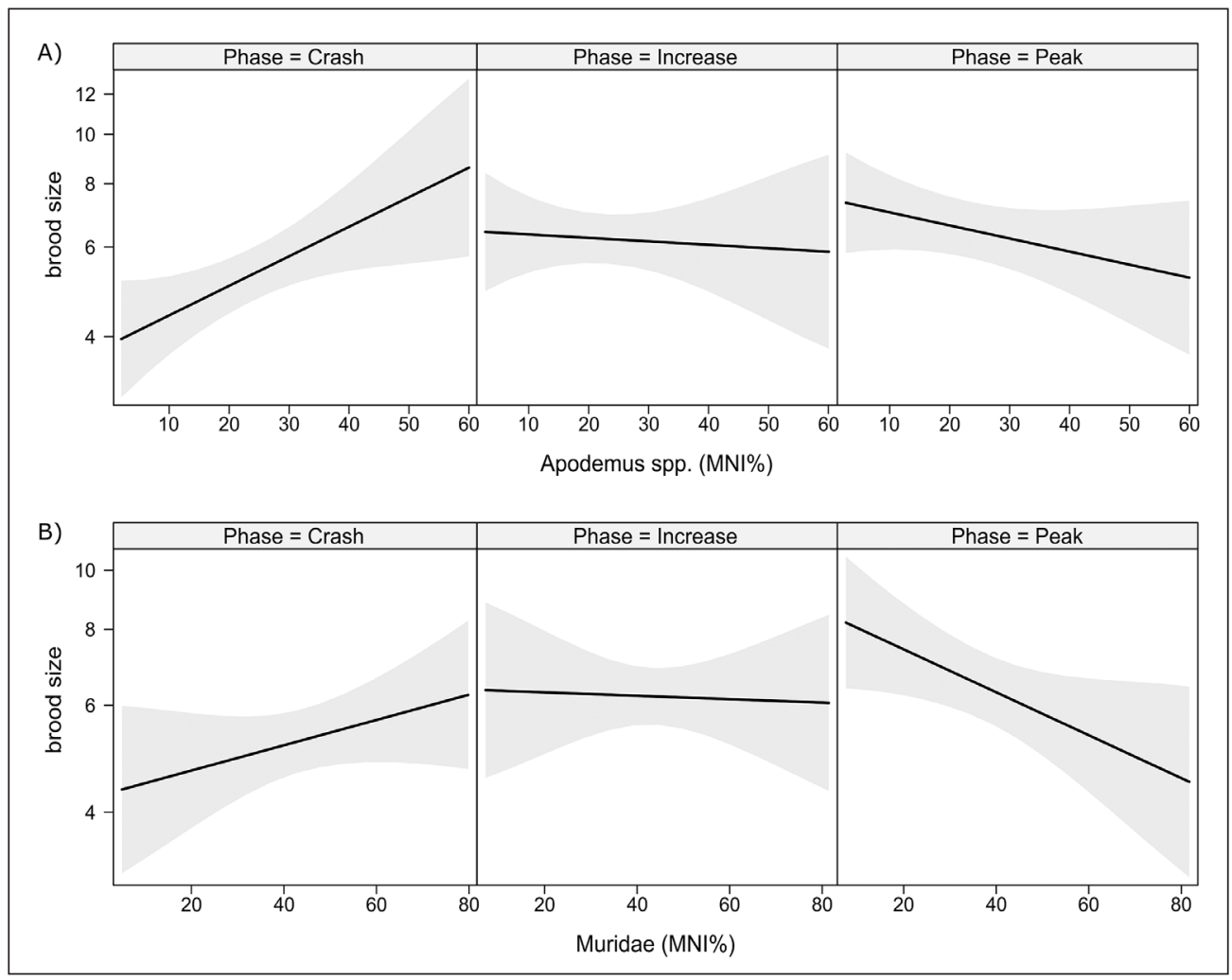

Figure 6. The interaction effect plot of the M1 model in case of Apodemus spp. (A) and Muridae (B) as potential alternative prey categories of the Common Barn-owl, showing the different impact of the two predictors on the variation of brood size during a given demographic phase of the Common Vole

6. ábra Az M1 modell interakciós hatás ábrái az Apodemus spp. (A) és a Muridae (B), mint a gyöngybagoly potenciális alternatív zsákmánykategóriái esetén, melyek a mezei pocok adott demográfiai fázisában mutatják e két prediktor különböző hatását a kikelt fiókák számának változására 
Table 5. Results of regression coefficient estimation in case of the breeding parameters (GLM model/explanatory variables and their interaction), showing only the significant results (For the abbreviations of the predictor variables see Material and Methods)

5. táblázat A regressziós koefficiens becslés eredményei a számolt szaporodási paraméterek esetén (GLM modell/magyarázó változók és ezek interakciói), csak szignifikáns eredményeket mutatva (A magyarázó változók rövidítését lásd a Material and Methods fejezetben)

\begin{tabular}{|c|c|c|c|c|c|}
\hline Model (ID) & Variable/Interaction & B & $\pm \mathrm{SE}$ & $\boldsymbol{t}$ & $\boldsymbol{P}$ \\
\hline \multicolumn{6}{|l|}{ clutch size } \\
\hline$\sim$ Mar × Region (M2) & Mar & 0.003 & 0.002 & 2.067 & $<0.05$ \\
\hline \multicolumn{6}{|l|}{ brood size } \\
\hline$\sim$ Mar $\times$ Region (M2) & Mar & 0.006 & 0.003 & 2.582 & $<0.05$ \\
\hline \multirow[t]{2}{*}{$\sim$ Muridae $\times$ Phase $(\mathrm{M} 1)$} & Phase-Peak & 0.696 & 0.226 & 3.081 & $<0.01$ \\
\hline & Muridae $\times$ Phase-Peak & -0.013 & 0.005 & -2.449 & $<0.05$ \\
\hline \multirow[t]{4}{*}{$\sim$ Asp $\times$ Phase (M1) } & Asp & 0.013 & 0.005 & 2.484 & $<0.05$ \\
\hline & Phase-Increase & 0.512 & 0.203 & 2.525 & $<0.05$ \\
\hline & Phase-Peak & 0.653 & 0.187 & 3.486 & $<0.001$ \\
\hline & Asp $\times$ Phase-Peak & -0.019 & 0.007 & -2.753 & $<0.01$ \\
\hline$\sim \mathrm{H}^{\prime} \times$ Region (M2) & $\mathrm{H}^{\prime}$ & -0.276 & 0.092 & -3.001 & $<0.01$ \\
\hline \multicolumn{6}{|l|}{ number of fledglings } \\
\hline \multirow[t]{3}{*}{$\sim$ Mar $\times$ Phase $(\mathrm{M} 2)$} & Mar & 0.013 & 0.004 & 3.700 & $<0.05$ \\
\hline & Region-MTBHC & 0.679 & 0.260 & 2.615 & $<0.05$ \\
\hline & Mar $\times$ Region-MTBHC & -0.012 & 0.005 & -2.318 & $<0.05$ \\
\hline \multirow[t]{3}{*}{$\sim \mathrm{H}^{\prime} \times$ Phase $(2)$} & $\mathrm{H}^{\prime}$ & -0.471 & 0.129 & -3.647 & $<0.001$ \\
\hline & Region-MTBHC & -0.674 & 0.322 & -2.092 & $<0.05$ \\
\hline & $\mathrm{H}^{\prime} \times$ Region-MTBHC & 0.501 & 0.202 & 2.482 & $<0.05$ \\
\hline \multirow[t]{3}{*}{$\sim$ LBMR $\times$ Phase $(\mathrm{M} 1)$} & Phase-Increase & 0.479 & 0.147 & 3.258 & $<0.01$ \\
\hline & Phase-Peak & 0.491 & 0.146 & 3.353 & $<0.01$ \\
\hline & LBMR $\times$ Phase-Peak & -0.130 & 0.053 & -2.452 & $<0.05$ \\
\hline
\end{tabular}

significant, but the main effect of Muridae was not an important predictor of brood size variation. As shown in the regression plot, proportion of Muridae significantly and positively affected the number of nestlings during the crash phase, while a significant negative relationship was detected between these variables in the peak phase, and the effect plot showed a weak regression with a non-significant negative slope (Table 5, Figure 6b).

The number of fledglings was affected by the proportion of Common Vole and by prey diversity ( $\mathrm{H}^{\prime}$ ) based on the best supported M2 model (Table 4). In case of the main prey, the effect of both model parameters and their interaction were significant (Mar: $\chi^{2}=13.03$, $P=0.0003$; Region: $\chi^{2}=6.79, P=0.0092$; Mar $\times$ Region: $\left.\chi^{2}=5.35, P=0.021\right)$. Considering the significant negative regression coefficient, the number of fledglings was influenced negatively by MTBHC compared to DFP region (Table 5). Based on the effect plot of the interaction, the proportion of the Common Vole significantly affected the number of fledglings in the DFP region but had no significant effect in the other mesoregion (MTBHC) (Figure 7a). 


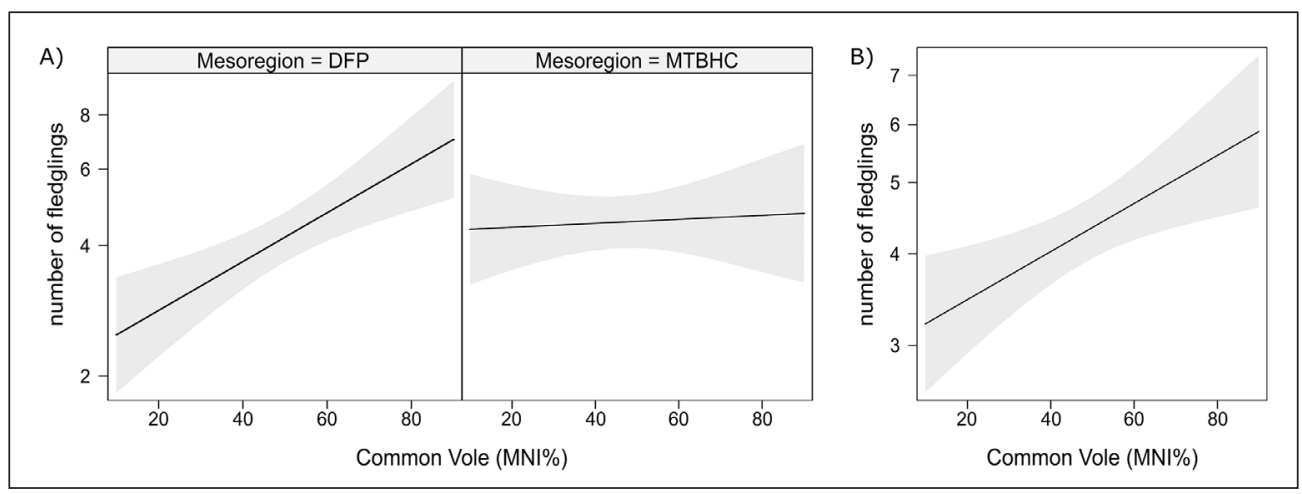

Figure 7. The interaction effect plot of the M2 model in case of the Common Vole, showing the different impact of this predictor on the variation of number of fledglings in the two investigated mesoregions $(A)$ and the relationship between relative abundance of the Common Vole and number of fledglings based on the main effect of the M2 model (B)

7. ábra AzM2 modell interakciós hatás ábrái a mezei pocok esetén, melyek a két vizsgált középtájban mutatják e prediktor különböző hatását a kirepült fiókák számának változására $(A)$, valamint a mezei pocok relatív abundancia és a kirepült fiókák száma közötti összefüggés az M2 modell főhatása alapján (B)

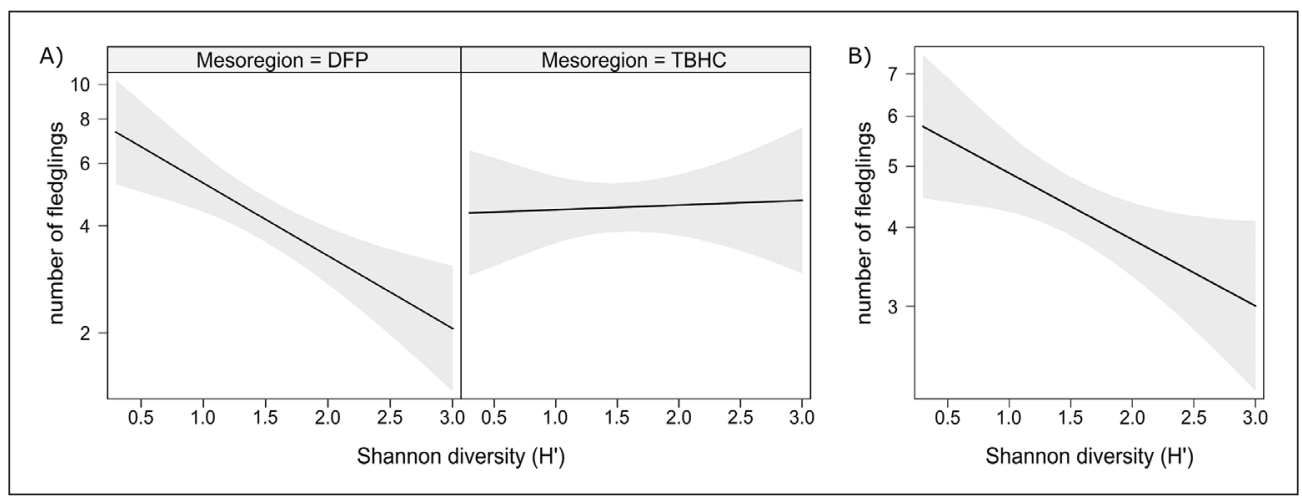

Figure 8. The interaction effect plot of the M2 model in case of Shannon diversity, showing the different impact of this predictor on the variation of number of fledglings in the two investigated mesoregions $(A)$ and the relationship between Shannon diversity and number of fledglings based on the main effect of the M2 model (B)

8. ábra Az M2 modell interakciós hatás ábrái a Shannon diverzitás esetén, melyek a két vizsgált középtájban mutatják e prediktor különböző hatását a kirepült fiókák számának változására (A), valamint a Shannon diverzitás és a kirepült fiókák száma közötti összefüggés az M2 modell föhatása alapján (B)

Visualization of the Common Vole's main effect demonstrated a significant positive relationship between the proportion of this main prey and the number of fledglings (Table 5, Figure $7 b$ ). Regarding the effect of prey diversity, a significant effect of both model parameters and their interaction were confirmed by the Type III test $\left(\mathrm{H}^{\prime}: \chi^{2}=12.63, P=0.0003\right.$; Region: $\chi^{2}=4.37, P=0.0365$; H' $\times$ Region: $\left.\chi^{2}=6.11, P=0.0135\right)$. The impact of diversity on the number of fledglings differed in the mesoregions, the significant positive regression 
Table 6. Quasi-Akaike's rank parameters of the candidate GLM models in case of the derived percentage values of successes (For the abbreviations of the predictor variables see Material and Methods)

6. táblázat Az alkalmazott GLM modellek Quasi-Akaike rang paraméterei a sikerek származtatott százalékos értékei esetén (A magyarázó változók rövidítését lásd a Materials and Methods fejezetben)

coefficient of the interaction indicated that the MTBHC region positively affected the brood size at fledging in contrast to the other mesoregion (DFP) (Table 5). The effect plots of interaction demonstrated a strong negative relationship between prey diversity and number of fledglings in the DFP region and a weaker positive regression between the two variables in case of MTBHC region (Figure 8a). Visualization of the main effect of Shannon diversity showed a significant negative relationship between diversity and brood size at fledging (Figure 8b). Furthermore, considering the large body mass rodents (LBMR) as potential alternative prey, the significant impact of Phase $\left(\chi^{2}=14.89, P=0.0006\right)$ and LBMR $\times$ Phase $\left(\chi^{2}=11.11\right.$, $P=0.0038$ ) was demonstrated by the Type III test, while the main effect of the LBMR prey category was not important in the best supported M1 model (Table 4). The significant estimated slope

\begin{tabular}{|c|c|c|c|}
\hline$Y_{i} /$ Predictor/Model (ID) & QAICc & $\Delta_{\mathrm{i}}$ & $\mathbf{w}_{\mathbf{i}}$ \\
\hline \multicolumn{4}{|l|}{ hatching success } \\
\hline \multicolumn{4}{|l|}{ Apodemus spp. } \\
\hline$\sim$ Asp $\times$ Phase $(\mathrm{M} 1)$ & 46.5 & 0.00 & 0.766 \\
\hline$\sim " \times$ Region (M2) & 48.9 & 2.39 & 0.232 \\
\hline$\sim " \times$ Phase $\times$ Region (M3) & 58.4 & 11.84 & 0.002 \\
\hline \multicolumn{4}{|l|}{ Crocidura leucodon } \\
\hline$\sim$ Cle $\times$ Region $(\mathrm{M} 2)$ & 42.5 & 0.00 & 0.947 \\
\hline$\sim " \times$ Phase (M1) & 48.4 & 5.96 & 0.048 \\
\hline$\sim " \times$ Phase $\times$ Region (M3) & 53.0 & 10.56 & 0.005 \\
\hline \multicolumn{4}{|l|}{ fledging success } \\
\hline \multicolumn{4}{|l|}{ Microtus arvalis } \\
\hline$\sim$ Mar $\times$ Region (M2) & 87.2 & 0.00 & 0.895 \\
\hline$\sim " \times$ Phase $(\mathrm{M} 1)$ & 92.0 & 4.78 & 0.082 \\
\hline$\sim " \times$ Phase $\times$ Region $(\mathrm{M} 3)$ & 94.6 & 7.39 & 0.023 \\
\hline \multicolumn{4}{|l|}{ Muridae } \\
\hline$\sim$ Muridae $\times$ Region (M2) & 89.1 & 0.00 & 0.773 \\
\hline$\sim \quad$ “ $\quad \times$ Phase (M1) & 91.8 & 2.75 & 0.196 \\
\hline$\sim \quad$ " $\times$ Phase $\times$ Region (M3) & 95.4 & 6.38 & 0.032 \\
\hline \multicolumn{4}{|l|}{ Apodemus spp. } \\
\hline$\sim$ Asp $\times$ Region (M2) & 89.2 & 0.00 & 0.616 \\
\hline$\sim " \times$ Phase $(\mathrm{M} 1)$ & 90.7 & 1.54 & 0.285 \\
\hline$\sim " \times$ Phase $\times$ Region $(\mathrm{M} 3)$ & 92.8 & 3.65 & 0.099 \\
\hline \multicolumn{4}{|l|}{ Shannon diversity $\left(\mathrm{H}^{\prime}\right)$} \\
\hline$\sim \mathrm{H}^{\prime} \times$ Region (M2) & 86.5 & 0.00 & 0.889 \\
\hline$\sim$ “ $\times$ Phase (M1) & 90.9 & 4.37 & 0.100 \\
\hline$\sim " \times$ Phase $\times$ Region (M3) & 95.2 & 8.68 & 0.012 \\
\hline \multicolumn{4}{|l|}{ LBMR } \\
\hline$\sim$ LBMR $\times$ Phase $(\mathrm{M} 1)$ & 86.6 & 0.00 & 0.773 \\
\hline$\sim \quad " \quad \times$ Region (M2) & 89.4 & 2.82 & 0.188 \\
\hline$\sim \quad " \quad \times$ Phase $\times$ Region (M3) & 92.6 & 5.97 & 0.039 \\
\hline \multicolumn{4}{|l|}{ reproductive success } \\
\hline \multicolumn{4}{|l|}{ LBMR } \\
\hline$\sim$ LBMR $\times$ Phase $(\mathrm{M} 1)$ & 98.9 & 0.00 & 0.990 \\
\hline$\sim \quad$ " $\times$ Region (M2) & 108.9 & 9.98 & 0.007 \\
\hline$\sim \quad$ " $\times$ Phase $\times$ Region (M3) & 110.3 & 11.40 & 0.003 \\
\hline
\end{tabular}

QAICc: Quasi-Akaike Information Criterion corrected for small sample size

$\Delta_{i}$ : QAICc differences $w_{i}$ : Akaike weights 
Table 7. Results of regression coefficient estimation in case of the derived percentage values of successes (GLM model/explanatory variables and their interaction), showing only the significant results (For the abridgment of the predictor variables see Material and Methods)

7. táblázat A regressziós koefficiens becslés eredményei a sikerek származtatott százalékos értékei esetén (GLM modell/magyarázó változók és ezek interakciói), csak szignifikáns eredményeket mutatva (A magyarázó változók rövidítését lásd a Material and Methods fejezetben)

\begin{tabular}{|c|l|c|c|c|c|}
\hline \multicolumn{1}{|c|}{ Model (ID) } & \multicolumn{1}{|c|}{ Variable/Interaction } & \multicolumn{1}{|c|}{ B } & \pm SE & \multicolumn{1}{c|}{ t } & P \\
\hline hatching success & & & & & \\
\hline$\sim$ Asp $\times$ Phase (M1) & Asp & 0.051 & 0.025 & 2.028 & $<0.05$ \\
\hline & Phase & 2.211 & 0.924 & 2.393 & $<0.05$ \\
\hline$\sim$ Cle $\times$ Region (M2) & Cle $\times$ Region-MTBHC & -0.302 & 0.128 & -2.351 & $<0.05$ \\
\hline fledging success & & & & & \\
\hline$\sim$ Mar $\times$ Region (M2) & Mar & 0.026 & 0.012 & 2.096 & $<0.05$ \\
\hline & Region-MTBHC & 1.967 & 0.845 & 2.329 & $<0.05$ \\
\hline$\sim$ Muridae $\times$ Region (M2) & Muridae $\times$ Region-MTBHC & 0.046 & 0.020 & 2.261 & $<0.05$ \\
\hline$\sim$ Asp $\times$ Region (M2) & Asp $\times$ Region-MTBHC & 0.066 & 0.029 & 2.249 & $<0.05$ \\
\hline$\sim$ LBMR $\times$ Phase (M1) & Phase & 1.612 & 0.490 & 3.292 & $<0.01$ \\
\hline & Phase-Peak & 1.013 & 0.423 & 2.395 & $<0.05$ \\
\hline & LBMR $\times$ Phase-Increase & -0.231 & 0.112 & -2.069 & $<0.05$ \\
\hline & LBMR $\times$ Phase-Peak & -0.214 & 0.095 & -2.255 & $<0.05$ \\
\hline$\sim$ D $\times$ Region (M2) & D & 3.974 & 1.741 & 2.283 & $<0.05$ \\
\hline & Region-MTBHC & 1.735 & 0.795 & 2.182 & $<0.05$ \\
\hline$\sim$ H' $\times$ Region (M2) & H' & -0.967 & 0.462 & -2.094 & $<0.05$ \\
\hline reproductive success & & & & & \\
\hline$\sim$ LBMR $\times$ Phase (M1) & Phase-Increase & 1.428 & 0.406 & 3.516 & $<0.001$ \\
\hline & Phase-Peak & -0.174 & 0.086 & -2.024 & $<0.05$ \\
\hline & LBMR $\times$ Phase-Peak & 0.362 & 2.306 & $<0.05$ \\
\hline & & & & \\
\hline
\end{tabular}

of the regression line indicated that the proportion of LBMR negatively affected the amount of fledglings in the peak phase compared to the crash phase of the Common Vole (Table 5).

The hatching success was affected by the proportion of wood mice (Apodemus spp.) and the relative consumption frequency of the Bicolored White-toothed Shrew. In case of the wood mice, M1, while in the case of Crocidura species, M2 was the best supported model to explain the relationship between the variables (Table 6). The analysis of deviance table showed that the main effect of Apodemus spp. $\left(\chi^{2}=4.51, P=0.0337\right)$ and Phase $\left(\chi^{2}=7.19, P=0.0274\right)$ was significant, but the interaction of these two variables did not prove to be an important predictor. Conversely, in case of M2 model of shrew species, the effect of the explanatory variables' (Cle $\times$ Region) interaction was significant $\left(\chi^{2}=8.51\right.$, $P=0.0035)$, however, the test did not confirm the importance of these variables as independent effects. The significant regression coefficient indicated a weaker positive relationship between the proportion of the Apodemus spp. and hatching success (Table 7), while a 


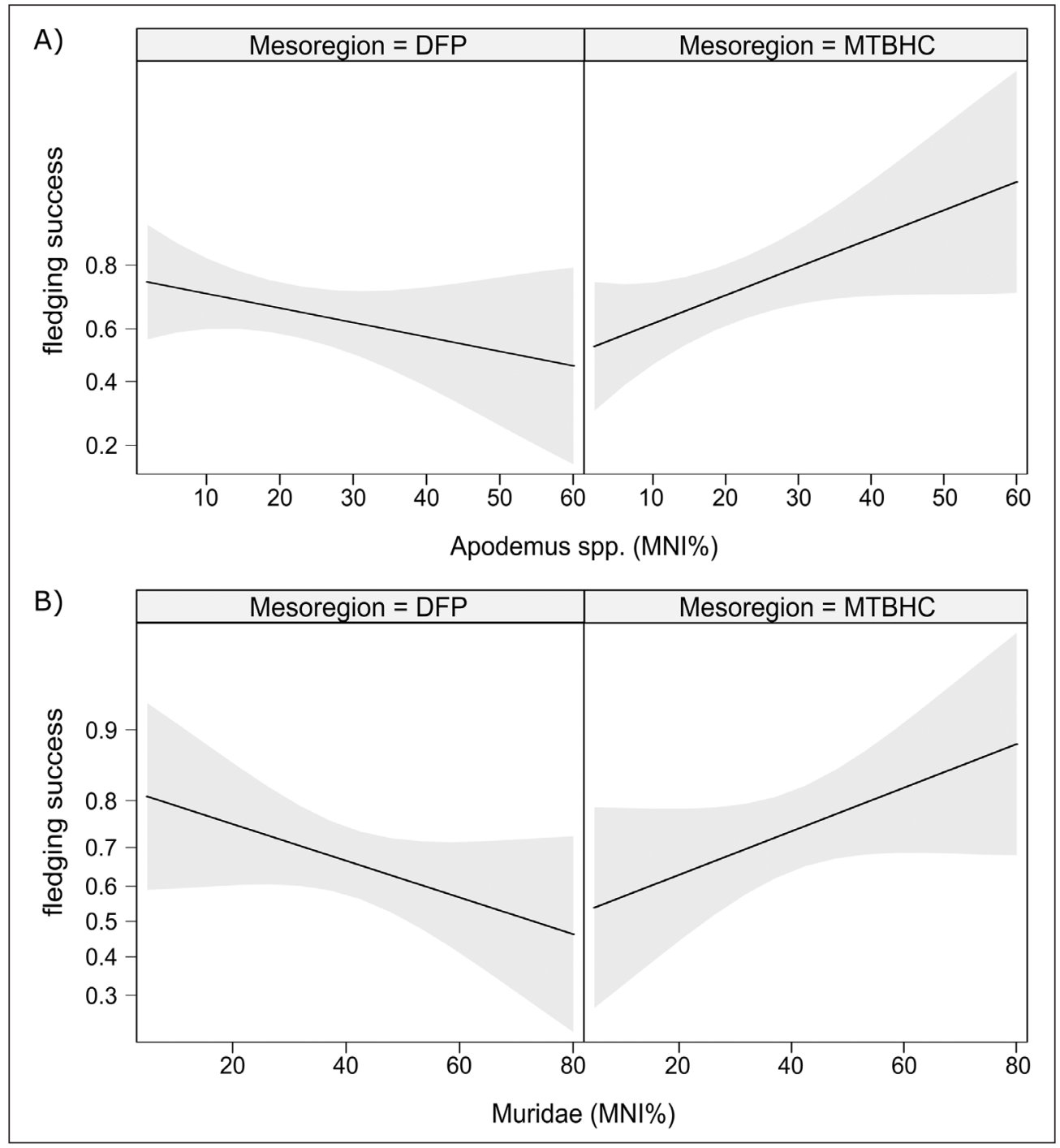

Figure 9. The interaction effect plot of the M2 model in case of Apodemus spp. (A) and Muridae (B) as potential alternative prey categories of the Common Barn-owl, showing the different impact of these predictors on the variation of fledging success in the two investigated mesoregions

9. ábra Az M2 modell interakciós hatás ábrái az Apodemus spp. (A) és a Muridae (B), mint a gyöngybagoly potenciális alternatív zsákmánykategóriái esetén, melyek a két vizsgált középtájban mutatják e prediktorok különböző hatását a kirepülési siker változására

negative relationship was detected by the estimated parameter between relative abundance of the Bicolored White-toothed Shrew and hatching success in the area of MTBHC compared to the other region (Table 7).

The fledging success was affected by the relative consumption rate of the Common Vole and the total proportion of the Apodemus spp. and Muridae, based on best supported M2 


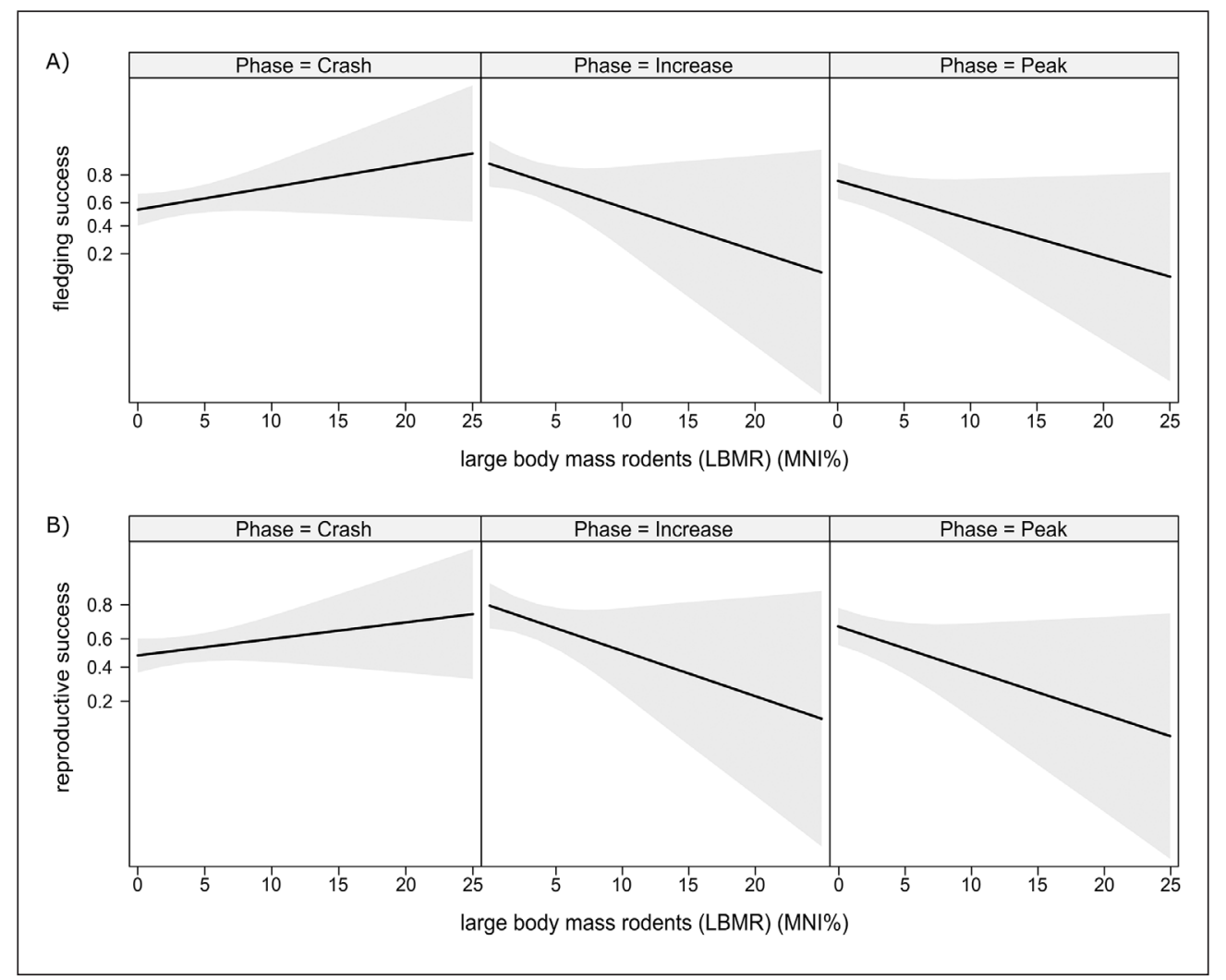

Figure 10. The interaction effect plot of the $\mathrm{M} 1$ model in case of fledging success (A) and reproductive success (B), showing the different impact of the abundance of large body mass rodents (LBMR) on the variation of fledging and reproductive success during a given demographic phase of the Common Vole

10. ábra Az M1 modell interakciós hatás ábrái a kirepülési siker (A) és a szaporodási siker (B) esetén, melyek a mezei pocok adott demográfiai fázisában mutatják a nagy testtömegű rágcsálók gyakoriságának hatását a kirepülési és szaporodási siker változására

model (Table 6). In case of the Common Vole, the significant main effect of predictors (Mar: $\chi^{2}=4.82, P=0.0282$; Region: $\left(\chi^{2}=5.66, P=0.0174\right)$ and their interaction was confirmed by the Type III test. The estimated parameter indicated a weaker but significant positive relationship between the proportion of the Common Vole and fledging success (Table 7). In case of Apodemus spp. as a potential alternative prey group, the interaction built into the M2 model had significant explanatory power $\left(\chi^{2}=5.44, P=0.0197\right)$, however, according to analysis of deviance table, the independent main effect of this predictor was not significant. Based on the positive estimated slope, the proportion of Apodemus spp. positively influenced the fledging success in the MTBHC mesoregion compared to the DFP region (Table 7). The opposite relationship in comparing the two landscapes was demonstrated by the effect plot of interaction (Figure 9a). Likewise, in case of Muridae, the Type III test of the best approximating M2 model (Table 6) confirmed the significant effect of the interaction $\left(\chi^{2}=5.35, P=0.0207\right)$ but rejected the importance of main effects. Compared to the 
DFL region, the relative proportion of this prey group positively affected the fledging success in the MTBHC region, thus the different effects of the two regions was expressed, which was visualized by the interaction effect plot (Figure 9b). Based on the effect test of the supported M2 model, the main effect of Shannon diversity was significant $\left(\chi^{2}=4.85\right.$, $P=0.0277$ ), contrary to the impact of Region and the interaction. According to the estimated slopes, a slight relationship was detected between prey diversity and fledging success (Table 7). In addition, the fledging success was affected by the cumulative proportion of large body mass rodents (LBMR) based on the most supported M1 model. Type III analysis showed that the main effect of Phase $\left(\chi^{2}=13.01, P=0.0015\right)$ and the impact of LBMR $\times$ Phase interaction $\left(\chi^{2}=9.37, P=0.0092\right)$ were significant. The estimated parameters indicated that the relative abundance of LBMR significantly and negatively affected fledging success in the increase and peak phase of the Common Vole compared to the crash phase (Table 7). The effect plot of the interaction demonstrated a weaker positive relationship between the aforementioned variables, indicating the importance of this prey group in the Barn Owl's diet during the low abundance phase of the Common Vole (Figure 10a).

Concerning reproductive success, we found significant effect in case of only one predictor variable. Similar to fledging success, we detected a significant relationship between the proportion of LBMR and reproductive success. Based on the best approximating M1 model, the significant main effect of Phase $\left(\chi^{2}=13.85, P=0.0009\right)$ and the interaction $\left(\chi^{2}=7.74\right.$, $P=0.0209)$ were confirmed by the Type III test. The significant estimated slope demonstrated that LBMR abundance negatively affected the reproductive success during the peak phase compared to the crash phase (Table 7). The interaction effect plot showed a weaker positive regression between this prey group and the response variable, similar to the results of fledging success (Figure 10b).

Considering the remaining investigated alternative prey categories, in case of the Sorex genus and the Striped Field Mouse we did not find evidence of significant relationship between the proportions of these prey items and any of the response variables reflecting the breeding performance of the Common Barn-owl.

\section{Discussion}

In the present study, we analysed the variation of breeding parameters and the diet composition of the Common Barn-owl in three different demographic phases of the Common Vole in a complete population cycle between two outbreaks. According to the results, we found that the Common Vole was the most abundant and thus, the main prey species in the barn owl's food composition based on our 5-year dataset from the two mesoregions. A similar predominance has been demonstrated by other studies in Central Europe (Horváth et al. 2005, 2018, Kitowski 2013, Petrovici et al. 2013, Purger 2014, Szép et al. 2017, 2019, Veselovský et al. 2017).

The mean value of the Common Vole's proportion derived from 81 randomly selected nesting pairs was lower in the peak phase than that reported in some earlier studies of the Common Barn-owl's trophic ecology. However, according to our result, the consumption 
rate of this main prey reflected significant difference between the crash $(=37.22 \%)$ and the outbreak $(=56.08 \%)$ phase. Bohnsack (1966) reported that the proportion of the Common Vole changed in a range between $63 \%$ and $95 \%$ during the outbreak and similarly high proportion (over 60\%) was published by Caboń-Raczyńska and Ruprecht (1977) in Poland, while a higher relative proportion (above 70\%) was determined in the food composition analysis of Common Barn-owls in gradation periods (De Bruijn 1979). Conversely, during the vole-poor and non-outbreak years, the Common Vole's consumption rate varied in a lower range (15-46\%) as characterized by authors cited above, which interval includes the minimum value $(13.12 \%)$ of vole consumption also shown in the present study. The examined period between the two outbreaks was characterized by a wider range (13-94\%) of Common Vole relative abundance than what was detected (17-81\%) in an earlier long-term analysis of the annual fluctuation of the Common Vole in the Common Barn-owl's diet in our study area (unpublished data).

We found significant difference in case of brood size, number of fledglings and reproductive success among the Common Vole demographic phases. Contrary to the expected result, all these three parameters were significantly higher in the increase than the crash phase. From the aspect of the importance of vole increase phase, our results are similar to those of other studies which detected that brood size was maximal during the increase phase as opposed to the peak phase (Korpimäki \& Hakkarainen 1991). In contrast with breeding performance values, we found more differences of small mammal prey categories among the vole demographic phases, and the differences were typical only in the crash phase in comparison of the investigated mesoregions. The proportion of more than one shrew categories were significantly higher in crash phase than during the peak phase (the importance of which is evaluated).

Clutch size is one of the most important life history traits of birds (Lack 1947, Price \& Liou 1989), which has been studied and discussed in the Common Barn-owl's breeding biology literature from different aspects, such as the comparison of first and second clutches (Marti 1994, Martínez \& López 1999, Frey et al. 2011, Bank et al. 2019), seasonal and annual variations of clutch size (Marti 1994, Martínez \& López 1999, Toms et al. 2001, Roulin 2002), and its relation to main prey abundance (Taylor 1994, Charter et al. 2015, Pavluvčík et al. 2015). In our regression analysis and modelling, we found that primarily the proportion of the Common Vole as main prey affected the variation of clutch size, where the independent main effect of this rodent was the most prevailing. These results presented that the increase of the Common Vole's consumption rate in the diet of owls resulted in an increase in clutch size, which is in accordance with results of some earlier studies (Schönfeld \& Girbig 1975, Braaksma \& de Bruijn 1976, De Jong 1983, De Bruijn 1994). Similar results were found in a study by Pavluvč́k et al. (2015) in which a positive relationship between the mean number of eggs and the vole abundance was shown. The positive relationship between clutch size and the vole consumption rate was described as a numerical response also in case of some vole-eating raptors (Korpimäki \& Norrdahl 1991, Jędrzejewski et al. 1994, Salamolard et al. 2000, Reif et al. 2004). Salamolard et al. (2000) demonstrated that mean clutch size of the Montagu's Harrier (Circus pygargus) was strongly correlated with spring vole abundance, while the average number of fledglings was correlated positively 
with summer vole abundance. In case of the Tawny Owl (Strix aluco), Solonen et al. (2015) pointed out that the mean clutch size of this owl species may be used to forecast abundance of voles typical in a given environment.

From the aspect of the potential indicator role of vole-eating owls' and raptors' breeding parameters, especially clutch size, these results are in accordance with those relationships obtained in the present study, namely that the clutch size of the Common Barn-owls is determined ultimately by the availability and consumption rate of the Common Vole as main prey. Moreover, the other investigated prey species or groups as predictors did not influence the annual variation of clutch size. These results supported the relevance of the 'vole specialist' character of the Common Barn-owl, similar to other vole-eating birds of prey (Salamolard et al. 2000, Romanowski \& Żmihorski 2008, Terraube et al. 2011, Tulis et al. 2015).

In addition, our results showed that the main effect of the Common Vole positively influenced the variation of the brood size, the number of fledglings and fledging success, but the vole consumption rate was not an important predictor in case of hatching and reproductive success as response variables. In contrast to our results, Frey et al. (2010) did not find relationship between the proportion of the Common Vole and breeding parameters, such as clutch and brood size and number of fledglings. Similar to our results, the dominant role of the Microtus prey items and the significant impact of its higher consumption rate on the breeding performance of the Common Barn-owl was reported in the Mediterranean region. Charter et al. (2015) found a positive correlation between abundance of social voles (Microtus socialis guentheri) and the number of fledglings despite the high cumulative proportion of the Murid rodents in the owls' diet, which was typical in the dry environments of the Middle East (Tores \& Yom-Tov 2003, Tores et al. 2005, Shehab \& Charabi 2006, Charter et al. 2009).

Considering the potential alternative prey of Common Barn-owl, we did not find significant relationship between the proportion of red-toothed shrews (Sorex genus) and reproductive parameters, which could be caused by this group of shrews being a subordinate prey category in the diet of owls in our study area and the examined period. Conversely, other studies found higher consumption rate of Sorex species (at the species or genus level) (Benedek et al. 2007, Bernard et al. 2010, Szücs et al. 2014, Baudrot et al. 2016). Benedek et al. (2007) reported a higher consumption frequency of Soricidae, which increased the diversity of diet and reflected a low abundance of rodents, particularly that of the Common Vole, although it was characteristic of only one of the two studied areas. Contrary to our results, this study demonstrated a selective predation in the direction of larger body mass shrews (S. araneus, C. leucodon). However, Common Barn-owls were characterized by non-breeding status in this locality, that is, the higher-diversity diet did not play a dominant role in the reproductive performance of owls (Benedek et al. 2007). Bernard et al. (2010) demonstrated that the proportions of Sorex genus in the diet did not correlate with their abundance in the field, while a negative correlation was observed between the consumption of Sorex spp. in the Barn Owl's diet and the abundance of the Common Vole. According to the results, this study pointed out that the frequency of a given prey in the diet depends also on the population density or availability of other species (Bernard et al. 2010), which has contributed to our understanding of the prey preference and switching mechanisms in a multi-prey context (Baudrot et al. 2016). 
We found that the consumption rate of the Crocidura prey groups (at the species and genus level) was higher than that of red-toothed shrews (Sorex genus), however, our result did not confirm that the total proportion of the shrews (Soricidae) and relative abundance at species or genus level (Sorex, Crocidura) would positively affect the reproductive parameters of the Barn Owl. Thus, our results do not support their role as alternative prey in the studied region. Moreover, the present study has shown a significant negative relationship between the prey diversity and the breeding performance (brood size, number of fledglings), which indicates that the diet composition of the Common Barn-owl is very diverse when the availability of Common Vole is very low, thus, our results are in accordance with other studies demonstrating that the shrew consumption increases in low abundance phases of the voles (Benedek et al. 2007, Bernard et al. 2010, Baudrot et al. 2016). This change of food composition was explained by optimal diet theory according to which the width of diet spectrum increases when the relative abundance of the main prey species decreases (Schoener 1971, Pyke et al. 1977, Salamolard et al. 2000).

Despite the fact that mice (Muridae), particularly the Apodemus species, representing a profitable prey group similar to Microtus voles, often occur as more abundant prey than voles in Mediterranean regions (Pezzo \& Morimando 1995, Varuzza et al. 2001, Bontzorolos et al. 2005, Tores et al. 2005, Charter et al. 2009), Charter et al. (2015) found a negative relationship between the consumption rate of mice and the number of fledglings. Our results are partly consistent with this observation, however, the negative relationship between the proportion of wood mice (Apodemus spp.) and the reproductive parameters (brood size, fledging success) was typical in the increase and during peak phase of the Common Vole. On the contrary, a positive regression was observed between the proportion of mice (Apodemus spp., Muridae) and the variation of the number of fledglings in the crash phase. In addition, we observed opposing effects of the Murid prey proportion between the two mesoregions, which reflected the different importance of mice in the food of Common Barn-owl. These results suggested that the wood mice (Apodemus spp.) and total Muridae can be characterized as important alternative prey groups with higher consumption rate in the diet of Barn Owls to compensate for the lack or lower availability of the main prey.

We found similar results in case of large body mass rodents as potential alternative prey group of owls. A positive regression with weaker slope was detected between their cumulative proportion in the diet and the reproductive parameters (number of fledglings, reproductive success). Some studies discussed the size-dependent predation of the Common Barn-owl (Kotler et al. 1988, Bellocq 1998, Roulin 2004b), which may significantly determine the composition of its diet, influencing the applicability of pellet analysis as an indirect method in surveys of small mammal assemblages (Yom-Tov \& Wool 1997, Leonardi \& Dell'Arte 2006, Zagoršek 2018). Our result suggested that the large body mass rodents may have an alternative prey role to compensate for the lack of the main prey in the low abundance phase of the Common Vole, however, the obtained results are not considered sufficient evidence to accept the alternative prey hypothesis in case of this prey category.

In summary, our results demonstrated that the clutch size of the Common Barn-owl is determined ultimately by the availability and consumption rate of the Common Vole as main prey, while other small mammal prey categories did not affect the clutch size. These results 
support the finding that the clutch size of vole-eating raptors and owls, which begin breeding in early spring, reflects the vole abundance of this early spring period. Considering the other investigated small mammal prey groups, only in case of the Murid rodent prey categories (Apodemus spp., Muridae) were alternative prey roles confirmed.

\section{Acknowledgments}

We thank the Churches of Baranya County, especially the Bishopric of Pécs and Reformed Congregations for providing opportunity to place nest boxes and supporting the breeding biology monitoring of owls and the systematic collection of the pellet samples. The members of the Baranya County Group of BirdLife Hungary and the enthusiastic volunteers of the 'Foundation for Natural Resources in Baranya' provided their generous help in the monitoring, cleaning and maintenance of the nest boxes. The pellet analysis of the Common Barn Owl was supported by Foundation for Natural Resources in Baranya, the Hungarian Biodiversity Monitoring System and the Duna-Dráva National Park Directorate. We thank the volunteers and university students for their dedicated work in helping us disassemble and process the owl pellets. Finally, we would like to thank the two anonymous reviewers for many helpful comments.

\section{References}

Angelstam, P., Lindström, E. \& Widén, P. 1984. Role of predation in short-term population fluctuations of some birds and mammals in Fennoscandia. - Oecologia 62: 199-208. DOI: 10.1007/BF00379014

Bank, L., Haraszthy, L., Horváth, A. \& Horváth, G. F. 2019. Nesting success and productivity of the Common Barn-owl Tyto alba: results from a nest box installation and long-term breeding monitoring program in Southern Hungary. - Ornis Hungarica 27(1): 1-31. DOI: 10.2478/orhu-2019-0001

Barton, K. 2016. MuMIn: multi-model inference. - R Package Vers. 1 (15), 6 http://CRAN.R-project.org/package=MuMIn.

Bates, D., Maechler, M., Bolker, B. \& Walker, S. 2015. Fitting linear mixed-effects models using lme4. - Journal of Statistical Software 67(1): 1-48. DOI: 10.18637/jss.v067.i01.

Baudrot, V., Perasso, A., Fritsch, C., Giraudoux, P. \& Raoul, F. 2016. The adaptation of generalist predators' diet in a multi-prey context: Insights from new functional responses. - Ecology 97(7): 1832-1841. DOI: $0.1890 / 15-0427.1$

Baudvin, H. 1979. Les secondes nichées chex la Chouette Effraie (Tyto alba) en Conte-d'Or [The second clutches of the Barn Owl Tyto alba]. - Nos Oiseanx 35: 125-134. (in French)

Bellocq, M. I. 2000. A review of the trophic ecology of the Barn Owl in Argentina. - Journal of Raptor Research 34(2): 108-119.

Benedek, A. M., Dumitru, A. \& Sbârcea, R. 2007. Correlation between diet and breeding of Tyto alba (Scopoli, 1769) (Aves: Tytonidae). - Travaux du Museum National d'Histoire Naturelle Grigore 1: 329-335.

Bernard, N., Michelat, D., Raoul, F., Quéré, J. P., Delattre, P. \& Giraudoux, P. 2010. Dietary response of Barn Owls (Tyto alba) to large variations in populations of Common Voles (Microtus arvalis) and European Water Voles (Arvicola terrestris). - Canadian Journal of Zoology 88(4): 416-426. DOI: 10.1139/Z10-011

Bohnsack, P. 1966. Über die Ernährung der Schleiereule, Tyto alba, insbesondere außerhalb der Brutzeit, in einem westholsteinischen Massenwechselgebiet der Feldmaus, Microtus arvalis [About the feeding of the Barn Owl, Tyto alba, especially outside the breeding season, in a West Holstein mass change area of the Field Vole, Microtus arvalis]. - Corax 1(17): 162-172. (in German) 
Bonvicino, C. R. \& Bezerra, A. M. 2003. Use of regurgitated pellets of Barn Owl (Tyto alba) for inventorying small mammals in the Cerrado of Central Brazil. - Studies Neotropical Fauna and Environment 38(1): 1-5. DOI: 10.1076/snfe.38.1.1.14030

Bontzorlos, V. A., Peris, S. J., Vlachos, C. G. \& Bakaloudis, D. E. 2005. The diet of Barn Owl in the agricultural landscapes of central Greece. - Folia Zoologica 54(1-2): 99-110.

Braaksma, S. \& de Bruijn, O. 1976. De kerkuilstand in Nederland [New data on Barn Owl in the Netherlands]. Limosa 49: 135-187. (in Dutch with English Summary)

Bryja, J., Tkadlec, E., Nesvadbova, J., Gaisler, J. \& Zejda, J. 2001. Comparison of enumeration and Jolly-Seber estimation of population size in the Common Vole Microtus arvalis. - Acta Theriologica 46: 279-285. DOI: 10.1007/BF03192434

Burnham, K. P. \& Anderson, D. R. 2002. Model selection and Inference: a practical information-theoretic approach. - Springer-Verlag, New York, 488 pp. DOI: 10.1007/b97636

De Bruijn, O. 1979. Voedseloecologie van de Kerkuil Tyto alba in Nederland [Food ecology of the Barn Owl Tyto alba in the Netherlands]. - Limosa 52: 91-154. (in Dutch with English Summary)

De Bruijn, O. 1994. Population ecology and conservation of the Barn Owl Tyto alba in farmland habitats in Liermers and Achterhoek (The Netherlands). - Ardea 82(1): 1-109.

De Jong, J. 1983. De Kerkuil [The Barn Owl]. - Kosmos, Utrecht, The Netherlands (in Dutch)

Dobson, A. J. \& Barnett, A. G. 2018. An introduction to generalized linear models. - Chapman \& Hall/CRC Texts in Statistical Science

Cabon-Raczyńska, K. \& Ruprecht, A. L. 1977. Estimation of population density of the Common Vole in Poland: an analysis of owl pellets. - Acta Theriologica 22(20-29): 349-354.

Campbell, R. W., Manuwal, D. A. \& Harestad, A. S. 1987. Food habits of the Common Barn Owl in British Columbia. - Canadian Journal of Zoology 65(3): 578-586. DOI: 10.1139/z87-090

Charter, M., Izhaki, I., Meyrom, K., Motro, Y. \& Leshem, Y. 2009. Diets of Barn Owls differ in the same agricultural region. - The Wilson Journal of Ornithology 121(2): 378-383. DOI: 10.1676/08-083.1

Charter, M., Izhaki, I., Leshem, Y., Meyrom, K. \& Roulin, A. 2015. Relationship between diet and reproductive success in the Israeli Barn Owl. - Journal of Arid Environments 122: 59-63. DOI: 10.1016/j.jaridenv.2015.06.011

Charter, M., Izhaki, I. \& Roulin, A. 2018. The relationship between intra-guild diet overlap and breeding in owls in Israel. - Population Ecology 60(4): 397-403. DOI: 10.1007/s10144-018-0633-6

Colvin, B. A. \& McLean, E. B. 1986. Food habits and prey specificity of the Common Barn Owl in Ohio. - Ohio Journal of Science 86(3): 76-80.

Dementavičius, D., Rumbutis, S., Virbickas, T., Vaitkuvienė, D., Dagys, M. \& Treinys, R. 2020. Spatial and temporal variations in the White-tailed Eagle Haliaeetus albicilla breeding diet revealed by prey remains. - Bird Study 67(2): 206-216. DOI: 10.1080/00063657.2020.1808591

Fay, R., Michler, S., Laesser, J., Jeanmonod, J. \& Schaub, M. 2020. Large-scale vole population synchrony in central Europe revealed by Kestrel breeding performance. - Frontiers in Ecology and Evolution 7: 512. DOI: $10.3389 /$ fevo.2019.00512

Fox, J., Weisberg, S., Friendly, M., Hong, J., Andersen, R., Firth, D., Taylor, S. \& R Core Team 2017. Package "effects". Effect Displays for Linear, and Other Models. Version 4.0-0. - https://cran.rproject.org/web/packages/effects/ effects.pdf

Frey, C., Sonnay, C., Dreiss, A. \& Roulin, A. 2011. Habitat, breeding performance, diet and individual age in Swiss Barn Owls (Tyto alba). - Journal of Ornithology 152(2): 279-290. DOI: 10.1007/s10336-010-0579-8

Gubanyi, J. A., Case, R. M. \& Wingfield, G. 1992. Diet and nesting success of Barn Owls breeding in western Nebraska. - American Midland Naturalist 127(2): 224-232. DOI: 10.2307/2426528

Hartig, F. 2017. DHARMa: residual diagnostics for hierarchical (multi-level/mixed) regression models. $\mathrm{R}$ package version $0.1,5(5)$.

Heywood, M. R. \& Pavey, C. R. 2002. Relative importance of plague rodents and dasyurids as prey of Barn Owls in central Australia. - Wildlife Research 29(2): 203-207. DOI: 10.1071/WR01104

Hindmarch, S. \& Elliott, J. E. 2015. A specialist in the city: the diet of Barn Owls along a rural to urban gradient. - Urban Ecosystems 18(2): 477-488. DOI: 10.1007/s11252-014-0411-y

Horváth, G., Molnár, D., Németh, T. \& Csete, S. 2005. Landscape ecological analysis of Barn Owl pellet data from the Drava lowlands, Hungary. - Natura Somogyiensis 7: 179-189.

Horváth, A., Morvai, A. \& Horváth, G. F. 2018. Food-niche pattern of the Barn Owl (Tyto alba) in intensively cultivated agricultural landscape. - Ornis Hungarica 26(1): 27-40. DOI: 10.1515/orhu-2018-0002 
Ille, R. 1991. Preference of prey size and profitability in Barn Owls Tyto alba guttata - Behaviour 116(3-4): 180189. DOI: $10.1163 / 156853991 X 00021$.

Jacob, J. \& Tkadlec, E. 2010. Rodent outbreaks in Europe: dynamics and damage. - In: Singleton, G., Belmain, S., Brown, P. R. \& Hardy, B. (eds.) Rodent outbreaks: Ecology and impacts - IRRI (International Rice Research Institute): Los Banos (Philippines), pp. 207-224.

Jacob, J., Manson, P., Barfknecht, R. \& Fredricks, T. 2014. Common Vole (Microtus arvalis) ecology and management: implications for risk assessment of plant protection products. - Pest Management Science 70(6): 869-878. DOI: 10.7325/Galemys.2016.A2

Jacob, J., Imholt, C., Caminero-Saldaña, C., Couval, G., Giraudoux, P., Herrero-Cófreces, S., Horváth, G. F., Luque-Larena, J. J., Tkadlec, E. \& Wymenga, E. 2020. Europe-wide outbreaks of Common Voles in 2019. Journal of Pest Science 93(2): 703-709. DOI: 10.1007/s10340-020-01200-2

Jędrzejewski, W., Jędrzejewska, B., Zub, K., Ruprecht, A. L. \& Bystrowski, C. 1994. Resource use by Tawny Owls Strix aluco in relation to rodent fluctuations in Białowieża National Park, Poland. - Journal of Avian Biology 25(4): 308-318. DOI: 10.2307/3677278

Kaus, D. 1977. Zur Populationsdynamik, Ökologie und Brutbiologie der Schleiereule Tyto alba in Franken [On the population dynamics, ecology and breeding biology of the Barn Owl Tyto alba in Franconia]. - Anzeiger der Omithologische Gesellschaft in Bayern 16: 18-44. (in German with English Summary)

Kitowski, I. 2013. Winter diet of the Barn Owl (Tyto alba) and the Long-eared Owl (Asio otus) in Eastern Poland. - North-western Journal of Zoology 9(1): 16-22.

Kleiber, C. \& Zeileis, A. 2008. Applied econometrics with R. - Springer-Verlag, New York DOI: 10.1007/9780-387-77318-6

Kleiber, C. \& Zeileis, A. 2009. AER: Applied Econometrics with R. - R package version 1.1.

Klok, C. \& De Roos, A. M. 2007. Effects of vole fluctuations on the population dynamics of the Barn Owl Tyto alba. - Acta Biotheoretica 55: 227-241. DOI: 10.1007/s10441-007-9013-x

Korpimäki, E. \& Norrdahl, K. 1989. Predation of Tengmalm's Owls: numerical responses, functional responses and dampening impact on population fluctuations of microtines. - Oikos 54(2): 154-164. DOI: 10.2307/3565261

Korpimäki, E., Huhtala, K. \& Sulkava, S. 1990. Does the year-to-year variation in the diet of Eagle and Ural Owls support the alternative prey hypothesis? - Oikos 58(1): 47-54. DOI: $10.2307 / 3565359$

Korpimäki, E. \& Hakkarainen, H. 1991. Fluctuating food supply affects the clutch size of Tengmalm's Owl independent of laying date. - Oecologia 85(4): 543-552. DOI: 10.1007/BF00323767

Korpimäki, E. \& Norrdahl, K. 1991. Numerical and functional responses of Kestrels, Short-eared Owls, and Long-eared Owls to vole densities. - Ecology 72(3): 814-826. DOI: 10.2307/1940584

Korpimäki, E., Norrdahl, K., Klemola, T., Pettersen, T. \& Stenseth, N. C. 2002. Dynamic effects of predators on cyclic voles: Field experimentation and model extrapolation. - Proceedings: Biological Sciences 269: 991997. DOI: 10.1098/rspb.2002.1972

Kotler, B. P., Brown, J. S., Smith, R. J. \& Wirtz, W. O. 1988. The effects of morphology and body size on rates of owl predation on desert rodents. - Oikos 53(2): 145-152. DOI: 10.1007/BF00328733

Kreiderits, A., Gamauf, A., Krenn, H. W. \& Sumasgutner, P. 2016. Investigating the influence of local weather conditions and alternative prey composition on the breeding performance of urban Eurasian Kestrels Falco tinnunculus. - Bird Study 63(3): 369-379. DOI: 10.1080/00063657.2016.1213791

Kryštufek, B. \& Macholán, M. 1998. Morphological differentiation in Mus spicilegus and the taxonomic status of mound-building mice from the Adriatic coast of Yugoslavia. - Journal of Zoology 245(2): 185-196. DOI: 10.1111/j.1469-7998.1998.tb00086.x

Lack, D. 1947. The significance of clutch-size. I and II. - Ibis 89: 302-352. DOI: 10.1111/j.1474-919X.1947.tb04155.x

Lambin, X., Bretagnolle, V. \& Yoccoz, N. G. 2006. Vole population cycles in northern and southern Europe: is there a need for different explanations for single pattern? - Journal of Animal Ecology 75(2): 340-349. DOI: 10.1111/j.1365-2656.2006.01051.x

Leonardi, G. \& Dell'Arte, G. L. 2006. Food habits of the Barn Owl (Tyto alba) in a steppe area of Tunisia. - Journal of Arid Environments 65(4): 677-681. DOI: 10.1016/j.jaridenv.2005.10.007

Luque-Larena, J. J., Mougeot, F., Vinuela, J., Jareno, D., Arroyo, L., Lambin, X. \& Arroyo, B. 2013. Recent largescale range expansion and outbreaks of the Common Vole (Microtus arvalis) in NW Spain. - Basic and Applied Ecology 14(5): 432-441. DOI: 10.1016/j.baae.2013.04.006

Macholán, M. 1996. Key to European House Mice (Mus). - Folia Zoologica 45(3): 209-217.

Marti, C. D. 1988. A long-term study of food-niche dynamics in the Common Barn Owl: comparisons within and between populations. - Canadian Journal of Zoology 66(8): 1803-1812. DOI: 10.1139/z88-261 
Marti, C. D. 1994. Barn Owl reproduction: patterns and variation near the limit of the species' distribution. - The Condor 96(2): 468-484. DOI: 10.2307/1369329

Marti, C. D. 2010. Dietary trends of Barn Owls in an agricultural ecosystem in Northern Utah. - Wilson Journal of Ornithology 122(1): 60-67. DOI: 10.1676/09-025.1

Martínez, J. A. \& López, G. 1999. Breeding ecology of the Barn Owl (Tyto alba) in Valencia (SE Spain). - Journal für Ornithologie 140(1): 93-99. DOI: 10.1007/BF02462093

McDowell, M. C. \& Medlin, G. C. 2009. The effects of drought on prey selection of the Barn Owl (Tyto alba) in the Strzelecki Regional Reserve, north-eastern South Australia. - Australian Mammalogy 31(1): 47-55. DOI: 10.1071/AM08115

Milchev, B. 2015. Diet of Barn Owl Tyto alba in Central South Bulgaria as influenced by landscape structure. Turkish Journal of Zoology 39(5): 933-940. DOI: 10.3906/zoo-1409-24

Milchev, B., Boev, Z. \& Kodjabashev, N. 2006. Breeding distribution and diet composition of the Barn Owl Tyto alba (Scopoli, 1769), (Aves: Strigiformes) in the North-Western Upper Thracian plain (Bulgaria). - Acta Zoologica Bulgarica 58(1): 83-92.

Millon, A. \& Bretagnolle, V. 2008. Predator population dynamics under a cyclic prey regime: numerical responses, demographic parameters and growth rates. - Oikos 117: 1500-1510. DOI: 10.1111/j.00301299.2008.16458.x

Paspali, G., Oruci, S., Koni, M., Wilson, I. F., Krystufek, B. \& Bego, F. 2013. Seasonal variation of small mammals in the diet of the Barn Owl (Tyto alba) in the Drinos River valley, southern Albania. - Turkish Journal of Zoology 37(1): 97-105. DOI: 10.3906/zoo-1203-25

Pavluvčík, P., Poprach, K., Machar, I., Losík, J., Gouveia, A. \& Tkadlec, E. 2015. Barn Owl productivity response to variability of vole populations. - PloS One 10(12): e0145851. DOI: 10.1371/journal.pone.0145851

Petrovici, M., Molnár, P. \& Sándor, A. D. 2013. Trophic niche overlap of two sympatric owl species (Asio otus Linnaeus, 1758 and Tyto alba Scopoli, 1769) in the North-Western part of Romania. - North-Western Journal of Zoology 9(2): 250-256.

Pezzo, F. \& Morimando, F. 1995. Food habits of the Barn Owl, Tyto alba, in a Mediterranean rural area: Comparison with the diet of two sympatric carnivores. - Italian Journal of Zoology 62(4): 369-373. DOI: $10.1080 / 11250009509356091$

Price, T. \& Liou, L. 1989. Selection on clutch size in birds. - The American Naturalist 134(6): 950-959. DOI: $10.1086 / 285023$

Purger, J. J. 2014. Survey of the small mammal fauna in north-western Somogy County (Hungary), based on Barn Owl Tyto alba (Scopoli, 1769) pellet analysis. - Natura Somogyiensis 24: 293-304.

Pyke, G. K., Pulliam, H. R. \& Charnov, E. L. 1977. Optimal foraging: a selective review of theory and tests. Quarterly Review of Biology 52: 137-154. DOI: 10.1086/409852

R Core Team 2019. R: a language and environment for statistical computing. - Vienna, Austria: R Foundation for Statistical Computing. Available at https:/www.R-project.org/

Reif, V., Tornberg, R., Jungell, S. \& Korpimäki, E. 2001. Diet variation of Common Buzzards in Finland supports the alternative prey hypothesis. - Ecography 24(3): 267-274. DOI: 10.1034/j.1600-0587.2001.240304.x

Reif, V., Jungell, S., Korpimäki, E., Tornberg, R. \& Mykrä, S. 2004. Numerical response of Common Buzzards and predation rate of main and alternative prey under fluctuating food conditions. - Annales Zoologici Fennici 41(4): 599-607.

Riegert, J., Lövy, M. \& Fainová, D. 2009. Diet composition of Common Kestrels Falco tinnunculus and Longeared Owls Asio otus coexisting in an urban environment. - Ornis Fennica 86(4): 123-130.

Romano, A., Séchaud, R. \& Roulin, A. 2020. Global biogeographical patterns in the diet of a cosmopolitan avian predator. - Journal of Biogeography 47(7): 1467-1481. DOI: 10.1111/jbi.13829

Rodríguez-Pastor, R., Escudero, R., Vidal, D., Mougeot, F., Arroyo, B., Lambin, X., Vila-Coro, A. M., Rodrígez-Moreno, I., Anda, P. \& Luque-Larena, J. J. 2017. Density-dependent prevalence of Francisella tularensis in fluctuating vole populations, northwestern Spain. - Emerging Infectious Diseases 23(8): 13771379. DOI: $10.3201 /$ eid2308.161194

Romanowski, J. \& Zmihorski, M. 2008. Effect of season, weather and habitat on diet variation of a feeding-specialist: a case study of the Long-eared Owl, Asio otus in Central Poland. - Folia Zoologica 57(4): 411-419.

Roulin, A. 2002. Short-and long-term fitness correlates of rearing conditions in Barn Owls Tyto alba. - Ardea 90(2): 259-267.

Roulin, A. 2004a Covariation between plumage colour polymorphism and diet in the Barn Owl (Tyto alba). - Ibis 146(3): 509- 517. DOI: 10.1111/j.1474-919x.2004.00292.x 
Roulin, A. 2004b Effects of hatching asynchrony on sibling negotiation, begging, jostling for position and within-brood food allocation in the Barn Owl Tyto alba. - Evolutionary Ecology Research 6(7): 1083-1098.

Salamolard, M., Butet, A., Leroux, A. \& Bretagnolle, V. 2000. Responses of an avian predator to variations in prey density at a temperate latitude. - Ecology 81(9): 2428-2441. DOI: 10.1890/0012-9658(2000)081[2428:RO AAPT] 2.0.CO;2

Sasvári, L., Hegyi, Z., Csörgő, T. \& Hahn, I. 2000. Age-dependent diet change, parental care and reproductive cost in Tawny Owls Strix aluco. - Acta Oecologica 21(4-5): 267-275. DOI: 10.1016/S1146-609X(00)01080-8

Schoener, T. W. 1971. Theory of feeding strategies. - Annual Review of Ecology and Systematics 11: 369-404. DOI: 10.1146/annurev.es.02.110171.002101

Schönfeld, M. \& Girbig, G. 1975. Beiträge zur Brutbiologie der Schleiereule, Tyto alba, unter besonderer Berücksichtigung der Abhängigkeit von der Feldmausdichte [Contribution to the breeding biology of the Barn Owl, Tyto alba, with special regard to the dependence on field density]. - Hercynia 12: 257-319. (in German with English Summary)

Shehab, A. H. \& Al Charabi, S. M. 2006. Food of the Barn Owl Tyto alba in the Yahmool Area, Northern Syria. Turkish Journal of Zoology 30(2): 175-179.

Sokal, R. R. \& Rohlf, F. J. 1997. Biometry. - W. H. Freeman and Co., New York

Solonen, T., Ahola, K. \& Karstinen, T. 2015. Clutch size of a vole-eating bird of prey as an indicator of vole abundance. - Environmental Monitoring and Assessment 187(9): 588-588. DOI: 10.1007/s10661-015-4783-0

Szép, D., Klein, Á. \& Purger, J. J. 2017. The prey composition of the Barn Owl (Tyto alba) with respect to landscape structure of its hunting area (Zala County, Hungary). - Ornis Hungarica 25(2): 51-64. DOI: 10.1515/ orhu-2017-0015

Szép, D., Klein, Á. \& Purger, J. J. 2019. Investigating the relationship between the prey composition of Barn Owls (Tyto alba) and the habitat structure of their hunting range in the Marcal Basin (Hungary), based on pellet analysis. - Ornis Hungarica 27(1): 32-43. DOI: 10.2478/orhu-2019-0002

Szűcs, D., Horváth, K. \& Horváth, G. F. 2014. Comparing small mammal faunas based on Barn Owl (Tyto alba) pellets collected in two different lowland landscapes. - Natura Somogyiensis 24: 305-320.

Taylor, I. 1994. Barn Owls. Predator-prey relationships and conservation. - Cambridge University Press, Cambridge

Terraube, J., Arroyo, B., Madders, M. \& Mougeot, F. 2011. Diet specialisation and foraging efficiency under fluctuating vole abundance: a comparison between generalist and specialist avian predators. - Oikos 120(2): 234244. DOI: $10.1111 /$ j.1600-0706.2010.18554.x

Tkadlec, E. \& Stenseth, N. C. 2001. A new geographical gradient in vole population dynamics. - Proceedings of the Royal Society of London, Series B: Biological Sciences 268(1476): 1547-1552. DOI: 10.1098/ rspb.2001.1694

Tome, D. 2003. Functional response of the Long-eared Owl (Asio otus) to changing prey numbers: a 20 -year study. - Ornis Fennica 80(2): 63-70.

Toms, M. P., Crick, H. Q. \& Shawyer, C. R. 2001. The status of breeding Barn Owls Tyto alba in the United Kingdom 1995-97. - Bird Study 48(1): 23-37. DOI: 10.1080/00063650109461200

Tores, M. \& Yom-Tov, Y. 2003. The diet of the Barn Owl Tyto alba in the Negev Desert. -Israel Journal of Ecology and Evolution 49(2-3): 233-236. DOI: 10.1560/JU3E-EWK4-13QY-CGRF

Tores, M., Motro, Y., Motro, U. \& Yom-Tov, Y. 2005. The Barn Owl - a selective opportunist predator. - Israel Journal of Ecology and Evolution 51(4): 349-360. DOI: 10.1560/7862-9E5G-RQJJ-15BE

Torre, I., Gracia-Quintas, L., Arrizabalaga, A., Baucells, J. \& Díaz, M. 2015. Are recent changes in the terrestrial small mammal communities related to land use change? A test using pellet analyses. - Ecological Research 30(5): 813-819. DOI: 10.1007/s11284-015-1279-x

Tóth, L. 2014. Numerical response of the Common Buzzard Buteo buteo to the changes in abundance of small mammals. - Ornis Hungarica 22(1): 48-56. DOI: 10.2478/orhu-2014-0010

Tulis, F., Baláž, M., Obuch, J. \& Šotnár, K. 2015. Responses of the Long-eared Owl Asio otus diet and the numbers of wintering individuals to changing abundance of the Common Vole Microtus arvalis. - Biologia 70(5): 667-673. DOI: 10.1515/biolog-2015-0074

Varuzza, P., Capizzi, D., Santini, L. \& Apollonio, M. 2001. Barn Owl Tyto alba predation on small mammals in relation to the Mediterranean environment (Pisa Province, Italy). - Acta Ornithologica 36(2): 153-160. DOI: 10.3161/068.036.0208

Veselovský, T., Bacsa, K. \& Tulis, F. 2017. Barn Owl (Tyto alba) diet composition on intensively used agricultural land in the Danube Lowland. - Acta Universitatis Agriculturae et Silviculturae Mendelianae Brunensis 65(1): 225-233. DOI: 10.11118/actaun201765010225 
Yom-Tov, Y. \& Wool, D. 1997. Do the contents of Barn Owl pellets accurately represent the proportion of prey species in the field? - The Condor 99(4): 972-976. DOI: 10.2307/1370149

Zar, J. H. 2010. Biostatistical Analysis, $5^{\text {th }}$ ed. - Pearson Prentice-Hall, Upper Saddle River, NJ.

Zagoršek, T. 2018. A contribution to the knowledge of diet composition of the Barn Owl Tyto alba in the area of Pisa (Italy). - Acrocephalus 39(178-179): 171-176.

Zárybnická, M., Sedláček, O., Salo, P., Št’astný, K. \& Korpimäki, E. 2015. Reproductive responses of temperate and boreal Tengmalm's Owl Aegolius funereus populations to spatial and temporal variation in prey availability. - Ibis 157(2): 369-383. DOI: 10.1111/ibi.12244

Zuur, A. F., Ieno, E. N., Walker, N. J., Saveliev, A. A. \& Smith, G. 2009. Mixed Effects Models and Extensions in Ecology with R. - Springer-Verlag, New York

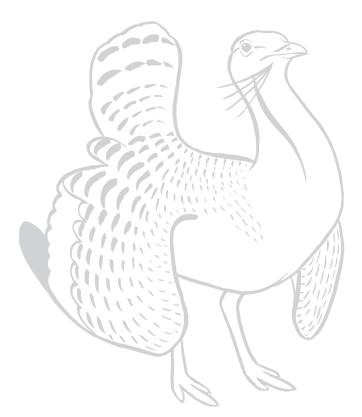

